\title{
Submicron aerosols at thirteen diversified sites in China: size distribution, new particle formation and corresponding contribution to cloud condensation nuclei production
}

\author{
J. F. Peng ${ }^{1}$, M. Hu ${ }^{1}$, Z. B. Wang ${ }^{1, *}$, X. F. Huang ${ }^{2}$, P. Kumar ${ }^{3,4}$, Z. J. Wu ${ }^{1}$, S. Guo ${ }^{1}$, D. L. Yue ${ }^{1}$, D. J. Shang ${ }^{1}$, Z. Zheng ${ }^{1}$, \\ and L. Y. He ${ }^{2}$ \\ ${ }^{1}$ State Key Joint Laboratory of Environmental Simulation and Pollution Control, College of Environmental Sciences and \\ Engineering, Peking University, Beijing 100871, China \\ ${ }^{2}$ Key Laboratory for Urban Habitat Environmental Science and Technology, School of Environment and Energy, Peking \\ University Shenzhen Graduate School, Shenzhen 518055, China \\ ${ }^{3}$ Department of Civil and Environmental Engineering, Faculty of Engineering and Physical Sciences (FEPS), University of \\ Surrey, Guildford GU2 7XH, UK \\ ${ }^{4}$ Environmental Flow (EnFlo) Research Centre, FEPS, University of Surrey, Guildford GU2 7XH, UK \\ * now at: Multiphase Chemistry Department, Max Planck Institute for Chemistry, Mainz 55128, Germany
}

Correspondence to: M. Hu (minhu@pku.edu.cn)

\begin{abstract}
Understanding the particle number size distributions in diversified atmospheric environments is important in order to design mitigation strategies related to submicron particles and their effects on regional air quality, haze and human health. In this study, we conducted 15 different field measurement campaigns between 2007 and 2011 at 13 individual sites in China, including five urban sites, four regional sites, three coastal/background sites and one ship cruise measurement along eastern coastline of China. Size resolved particles were measured in the $15-600 \mathrm{~nm}$ size range. The median particle number concentrations (PNCs) were found to vary in the range of $1.1-2.2 \times 10^{4} \mathrm{~cm}^{-3}$ at urban sites, $0.8-1.5 \times 10^{4} \mathrm{~cm}^{-3}$ at regional sites, $0.4-0.6 \times 10^{4} \mathrm{~cm}^{-3}$ at coastal/background sites, and $0.5 \times 10^{4} \mathrm{~cm}^{-3}$ during cruise measurement. Peak diameters at each of these sites varied greatly from 24 to $115 \mathrm{~nm}$. Particles in the $15-25 \mathrm{~nm}$ (nucleation mode), $25-100 \mathrm{~nm}$ (Aitken mode) and 100-600 nm (accumulation mode) range showed different characteristics at each sites, indicating the features of primary emissions and secondary formation in these diversified atmospheric environments. Diurnal variations show a build-up of accumulation mode particles belt at regional sites, suggesting the contribution of regional secondary aerosol pollution. Frequencies of new particle formation (NPF) events were much higher at urban and regional sites than at coastal sites and during cruise measurement. The average growth rates (GRs)
\end{abstract}

of nucleation mode particles were $8.0-10.9 \mathrm{~nm} \mathrm{~h}^{-1}$ at urban sites, $7.4-13.6 \mathrm{~nm} \mathrm{~h}^{-1}$ at regional sites and $2.8-7.5 \mathrm{~nm} \mathrm{~h}^{-1}$ at coastal sites and during cruise measurement. The high gaseous precursors and strong oxidation at urban and regional sites not only favored the formation of particles, but also accelerated the growth rate of the nucleation mode particles. No significant difference in condensation sink (CS) during NPF days were observed among different site types, suggesting that the NPF events in background areas were more influenced by the pollutant transport. In addition, average contributions of NPF events to potential cloud condensation nuclei $(\mathrm{CCN})$ at $0.2 \%$ super-saturation in the afternoon of all sampling days were calculated as $11 \%$ and $6 \%$ at urban sites and regional sites, respectively. On the other hand, NPF events at coastal sites and during cruise measurement had little impact on potential production of CCN. This study provides a large data set of particle size distribution in diversified atmosphere of China, improving our general understanding of emission, secondary formation, new particle formation and corresponding $\mathrm{CCN}$ activity of submicron aerosols in Chinese environments. 


\section{Introduction}

Atmospheric particles play an important role in the degradation of visibility and changing the balance of global radiative forcing (Dusek, 2006; IPCC, 2007), besides showing adverse impacts on human health (Heal et al., 2012). Size of atmospheric particles, ranging from $1.5 \mathrm{~nm}$ up to hundreds of micrometers, is a key factor for evaluating environmental effects of particles (Kulmala et al., 2013; Buseck and Adachi, 2008; Kumar et al., 2014). For example, particle diameter is considered to be more important than chemical composition for cloud-nucleating ability (Dusek, 2006). Smaller particles may have greater potential of health impacts compared with their larger counterparts (WHO, 2013). Particles smaller than $100 \mathrm{~nm}$ in diameter (ultrafine particles) have deeper deposition in human body and are able to induce more intense oxidative stress in cells (Nel et al., 2006). Accumulation mode particles, on the other hand, have high light extinction efficiency and can explain degradation of visibility in severe air pollution event to a great extent (See et al., 2006). Meanwhile, particle size distribution offers information on type, origin, and atmospheric transformation of the particles (Buseck and Adachi, 2008; Harrison et al., 2011). Therefore, the knowledge of size distributions of submicron particles, including their temporal and spatial variability, is crucial in characterizing human exposure, estimating climate effects, and designing monitoring strategies for both developed and developing countries (Kumar et al., 2014).

Measurements of particle number distribution (PND) have been extensively conducted in many European and US sites in the past 2 decades (Asmi et al., 2011a; Bigi and Ghermandi, 2011; Borsos et al., 2012; Kumar et al., 2010; Wehner and Wiedensohler, 2003), but at a much lesser extent in developing countries (Monkkonen et al., 2005; Wu et al., 2008; Kumar et al., 2011; Wang et al., 2013a, b). Temporal and spatial variation of PND in these developed countries has been widely recognized (Asmi et al., 2011a). Whilst these particles arise from a number of non-vehicle exhaust sources (Kumar et al., 2013b), primary emission from road vehicles is thought to be a main source of particle number concentration (PNC) in urban areas (Kumar et al., 2010).

The new particle formation (NPF), associated with a rapid burst of nucleation mode particles, results in an increase of cloud condensation nuclei (CCN) number concentration after growth (Wiedensohler et al., 2009). The NPF events were observed in many atmospheric environments in the world, especially in relatively clean atmosphere (Kulmala et al., 2013). Though the first study on NPF events during polluted episodes was conducted in the megacity of Beijing (Wehner et al., 2004; Wu et al., 2007), the occurrence of NPF events is only reported at a few sites in China up to now (Du et al., 2012; Liu et al., 2008; Wang et al., 2013c; Wehner et al., 2004; Wiedensohler et al., 2009; Herrmann et al., 2014). Although it is a common interest that regional NPF events are a main source of atmospheric $\mathrm{CCN}$ production (Kuang et al., 2009), most of the estimation on the contribution of NPF events to CCN concentration till date are only based on model simulations using regional/global scale models with extra NPF mode (Merikanto et al., 2009; Yu et al., 2012). The only few measurement studies that attempted to quantify the strength of this nucleation process merely calculated the enhancement of CCN concentration along with NPF events (Yue et al., 2011; Kerminen et al., 2012; Kuang et al., 2009; Asmi et al., 2011b). These enhancement results are likely to be greatly influenced by other factors such as change of boundary layer as well as primary emissions. More measurements and new measurement-based approaches are therefore needed to estimate the contribution of NPF to corresponding $\mathrm{CCN}$ concentration in diversified environments.

China has been experiencing unprecedented modernization and urbanization process since the 1980s. The rapid industrial revolution has intensively occurred in China during the past 30 years, providing both the chance to become "the world factory" and the challenge of severe air pollution problem. The aerosol pollution in recent years at both local and regional scale has attracted great attention, as it results in the heavy smog or haze episodes and might lead to potential health effects (Xu et al., 2013). The aerosol pollution characterizes regional property in major economic developed regions with megacity or city clusters, for instance, Bohai Sea rim region, Yangtze River delta and Pearl River delta. To understand the feature of aerosol pollution in these regions requires multi-site measurements within each pollution region.

In this study, we have therefore conducted PND measurements at 13 different sites in China in order to provide comprehensive understanding of the effects of primary emissions, regional pollutants transportation and new particle formation on PNDs. These sites are classified into four main categories - urban, regional, coastal and ship cruising - representing the typical atmospheric environments in China. Unique features of each site category, including the particle size distributions, seasonal and diurnal variation, are discussed in this paper. Special focus is given to the NPF events and their contribution to $\mathrm{CCN}$ concentration at each of the thirteen sites.

\section{Methodology}

\subsection{Sites description}

A total of 15 field measurement campaigns of PNDs were conducted at 13 different sites between 2007 and 2011. These sites are broadly classified in the following four types according to the atmospheric environments (see Table 1), including five urban sites, four regional sites, three coastal/background sites and one ship cruise measurement along Eastern coastal China. As shown in Fig. 1, most of these sites were situated in the most developed and largest city cluster regions in China. 
Table 1. Summary of information providing description of sampling periods at each measurement site. Please note that the words in parenthesis against each site represent a short name of each site, and subscripts $\mathrm{u}, \mathrm{r}, \mathrm{c}$ and s indicate urban, regional, background/coastal and cruise site types, respectively.

\begin{tabular}{lllll}
\hline Type & Sites & Coordinates & Sampling period & Valid data \\
\hline Urban & Guangzhou $\left(\mathrm{GZ}_{\mathrm{u}}\right)$ & $23.13^{\circ} \mathrm{N}, 113.26^{\circ} \mathrm{E}$ & 12-29 November 2010 & 4766 \\
& Shanghai $\left(\mathrm{SH}_{\mathrm{u}}\right)$ & $31.23^{\circ} \mathrm{N}, 21.53^{\circ} \mathrm{E}$ & 15 April-22 June 2010 & 18658 \\
& Urumchi $\left(\mathrm{UC}_{\mathrm{u}}\right)$ & $87.58^{\circ} \mathrm{N}, 43.83^{\circ} \mathrm{E}$ & 16 May-2 June 2008 & 4835 \\
& Wuxi $\left(\mathrm{WX}_{\mathrm{u}}\right)$ & $31.56^{\circ} \mathrm{N}, 120.29^{\circ} \mathrm{E}$ & 21 July-7 August 2010 & 4769 \\
& & & $1-14$ January 2011 & 4926 \\
& Jinhua $\left(\mathrm{JH}_{\mathrm{u}}\right)$ & $29.1^{\circ} \mathrm{N}, 119.69^{\circ} \mathrm{E}$ & 29 October-28 November 2011 & 7776 \\
\hline Regional & Heshan $\left(\mathrm{HS}_{\mathrm{r}}\right)$ & $22.71^{\circ} \mathrm{N}, 112.93^{\circ} \mathrm{E}$ & 12-29 November 2010 & 4921 \\
& Kaiping $\left(\mathrm{KP}_{\mathrm{r}}\right)$ & $22.33^{\circ} \mathrm{N}, 112.54^{\circ} \mathrm{E}$ & 18 October-17 November 2008 & 8465 \\
& Jiaxing $\left(\mathrm{JX}_{\mathrm{r}}\right)$ & $30.8^{\circ} \mathrm{N}, 120.8^{\circ} \mathrm{E}$ & 28 June-15 July 2010 & 4564 \\
& & & $5-22$ December 2010 & 4030 \\
& Yufa $\left(\mathrm{YF}_{\mathrm{r}}\right)$ & $39.51^{\circ} \mathrm{N}, 116.3^{\circ} \mathrm{E}$ & 5-31 October 2007 & 5182 \\
\hline Coastal/ Background & Baguang $\left(\mathrm{BG}_{\mathrm{c}}\right)$ & $22.65^{\circ} \mathrm{N}, 114.54^{\circ} \mathrm{E}$ & 25 October-3 December 2009 & 5895 \\
& Wenling $\left(\mathrm{WL}_{\mathrm{c}}\right)$ & $28.40^{\circ} \mathrm{N}, 121.61^{\circ} \mathrm{E}$ & 30 Oct-28 November 2011 & 7064 \\
& Changdao $\left(\mathrm{CD}_{\mathrm{c}}\right)$ & $37.99^{\circ} \mathrm{N}, 120.70^{\circ} \mathrm{E}$ & 19 March-24 April 2011 & 10338 \\
\hline Cruise & East China Sea $\left(\mathrm{ES}_{\mathrm{s}}\right)$ & - & 18 March-8 April 2011 & 5015 \\
\hline
\end{tabular}

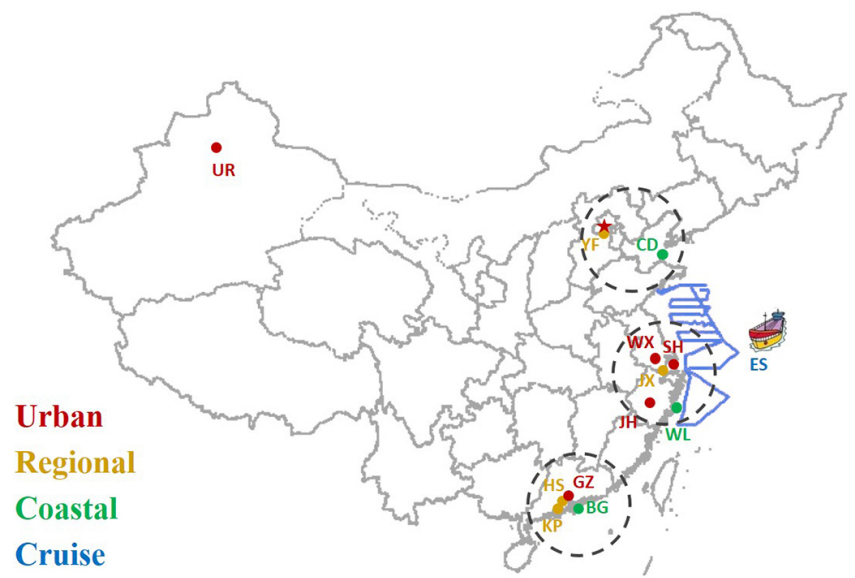

Figure 1. The location of all the thirteen measurement sites. Red, yellow and green color dots and blue line represent the sites types of urban, regional, costal and cruise. Black circles show the three largest urban areas in China.

\subsubsection{Urban sites}

The first urban site, Guangzhou $\left(\mathrm{GZ}_{\mathrm{u}} ; 23.13^{\circ} \mathrm{N}, 113.26^{\circ} \mathrm{E}\right)$ was located on the roof of the Guangdong Provincial Environmental Monitoring Center in the downtown of Guangzhou city, at a height of about $50 \mathrm{~m}$ above street level (Yue et al., 2013). This site is representative of a typical ambient condition in Guangzhou urban areas (Zhang et al., 2008).

The second urban site, Shanghai $\left(\mathrm{SH}_{\mathrm{u}} ; 21.53^{\circ} \mathrm{E}\right.$, $31.23^{\circ} \mathrm{N}$ ), was located on the roof of a six-floor building of Shanghai Pudong Environmental Monitoring Station in the eastern part of Shanghai urban areas. The surroundings of this site were mainly residential and business buildings (Huang et al., 2012).

The third urban site, Urumchi $\left(\mathrm{UR}_{\mathrm{u}} ; 87.58^{\circ} \mathrm{N}, 43.83^{\circ} \mathrm{E}\right)$, was located on roof of the Urumchi Environmental Monitoring Center in the downtown of Urumchi city. Urumchi city is the capital of Xinjiang Uyghur Autonomous Region, with the biggest desert in China to the north and mountains to the south. Sampling inlet at $\mathrm{UR}_{\mathrm{u}}$ site was located at $\sim 20 \mathrm{~m}$ above the street level. The surroundings were mainly residential and business buildings. There was one main road $200 \mathrm{~m}$ away to the west and another $400 \mathrm{~m}$ away to the east.

The fourth urban site, Wuxi $\left(\mathrm{WX}_{\mathrm{u}} ; 31.56^{\circ} \mathrm{N}, 120.29^{\circ} \mathrm{E}\right)$, was located on the roof of a five-floor building in the center of Wuxi city. This site was surrounded by the residential buildings. No obvious stationary sources existed nearby and the nearest main road was about $300 \mathrm{~m}$ away to the east. The sampling inlet was at $\sim 15 \mathrm{~m}$ above the ground level.

The fifth urban site, Jinhua $\left(\mathrm{JH}_{\mathrm{u}} ; 29.1^{\circ} \mathrm{N}, 119.69^{\circ} \mathrm{E}\right)$, was located on the roof of the Jindong Environmental Building in the east part of the city of Jinhua. The sampling inlet was at $\sim 25 \mathrm{~m}$ above the street level. There was no industry source nearby and the nearest main road was located $\sim 300$ m away to the west. As the wind direction is always from the northeast during the measurements (October), the influence of this main road on our site can be ignored.

\subsubsection{Regional sites}

The first regional site, Heshan $\left(\mathrm{HS}_{\mathrm{r}} ; 22.71^{\circ} \mathrm{N}, 112.93^{\circ} \mathrm{E}\right)$, was an urban outflow site of Guangzhou megacity in central Pearl River delta (PRD), with a distance from Guangzhou 
downtown $50 \mathrm{~km}$. It was located on the top of a small hill $(40 \mathrm{~m})$, about $7 \mathrm{~km}$ away from Heshan downtown areas, and was far from any industrial sources. The surrounding areas of the site were dominated by farmlands and forests. Biomass burning events were observed occasionally in the farmlands. This site can be well representative of the air pollution outflow from the polluted central PRD urban areas (Gong et al., 2012).

The second regional site, Kaiping $\left(\mathrm{KP}_{\mathrm{r}} ; 22.33^{\circ} \mathrm{N}\right.$, $112.54^{\circ} \mathrm{E}$ ), was located $\sim 120 \mathrm{~km}$ away from the city of Guangzhou to the southwest. Under the influence of the Asian monsoon, the dominant air mass comes to PRD from the northeast in fall. Hence, the Kaiping site could be assumed to be a downwind receptor site. Instruments were placed on the third floor of the building at the Kaiping supersite ( $\sim 10 \mathrm{~m}$ above the ground level), which is surrounded by shrubs and eucalyptus forest (Wang et al., 2013c). The site was free of any significant local pollution emissions. A detailed geographic description of this measurement site can be seen elsewhere (Huang et al., 2011).

The third regional site, Jiaxing $\left(\mathrm{JX}_{\mathrm{r}} ; 30.8^{\circ} \mathrm{N}, 120.8^{\circ} \mathrm{E}\right)$, was a suburban site between Shanghai and Hangzhou. It was located on the roof of school building in a small town, $15 \mathrm{~m}$ above the ground level and $8 \mathrm{~km}$ away from the downtown of Jiaxing city, which was situated in the middle of Shanghai megacity and Hangzhou, capital of Zhejiang province.

The fourth regional site, Yufa $\left(\mathrm{YF}_{\mathrm{r}} ; 39.51^{\circ} \mathrm{N}, 116.3^{\circ} \mathrm{E}\right)$, was about $40 \mathrm{~km}$ to the south of Beijing downtown area. This site was located on top of a building ( $\sim 20 \mathrm{~m}$ above the ground level) at the campus of Huangpu College. There were no industrial sources around this site, except the farm land and a residential area (Guo et al., 2010).

\subsubsection{Three coastal/background sites}

The first coastal site, Baguang $\left(\mathrm{BG}_{\mathrm{c}} ; 22.65^{\circ} \mathrm{N}, 114.54^{\circ} \mathrm{E}\right)$, was located on the roof of a three-floor building $(\sim 10 \mathrm{~m}$ above sea level) at the seaside in a small peninsula in the southern China, $50 \mathrm{~km}$ away from the city of Shenzhen to the east. No stationary source or traffic source was found nearby the site. To the east and south of the site was the South China Sea. This site can well represent the background atmosphere of southern China during autumn.

The second coastal site, Wenling $\left(\mathrm{WL}_{\mathrm{c}} ; 28.40^{\circ} \mathrm{N}-\right.$ $121.61^{\circ} \mathrm{E}$ ), was situated in a flat ground area in a peninsula in the southeast of China, surrounding by only farmland. The sampling inlet was about $4 \mathrm{~m}$ above the ground level. The East China Sea was up to $2 \mathrm{~km}$ away from the site to the northeast and southeast. The city of Taizhou was about $30 \mathrm{~km}$ away to the northwest of the site. Wind direction ranged from north to east during the whole campaign at $\mathrm{WL}_{\mathrm{c}}$ site, resulting in a variety of air masses that can be encountered from modified clean maritime air mass to polluted continental air mass.
The third coastal site, Changdao $\left(\mathrm{CD}_{\mathrm{c}} ; 37.99^{\circ} \mathrm{N}\right.$, $120.70^{\circ} \mathrm{E}$ ), was located at $\sim 50 \mathrm{~m}$ above the sea level on a hill in the north coast of Changdao island. This island lies offshore to the east edge of central eastern China and laid between the Jiaodong and the Liaodong Peninsula in the Bohai Sea. A detailed geographic description of the measurement site is presented in (Hu et al., 2013).

\subsubsection{Ship cruise measurement}

Ship cruise measurement $\left(\mathrm{ES}_{\mathrm{S}}\right)$ was carried out on the "Dong Fang Hong 2", which is a multi-functional marine research vessel (http://eweb.ouc.edu.cn/4b/61/c4169a19297/ page.htm). The observatory was located on the 6th floor of the "Dong Fang Hong 2", which was about $15 \mathrm{~m}$ above the sea level. The vessel sailed from Qingdao of Shandong province $\left(24.5^{\circ} \mathrm{N}, 118.1^{\circ} \mathrm{E}\right)$ on 17 March, reached the southernmost area of the cruise near Wenzhou of Zhejiang province on 27 March, and returned at Qingdao $\left(24.5^{\circ} \mathrm{N}\right.$, $118.1^{\circ} \mathrm{E}$ ) on 9 April. The study area of the whole cruse covered both the East China Sea and Yellow Sea of China (see Fig. 1).

\subsection{Instrumentation}

The Scanning Mobility Particle Sizer (SMPS, TSI Inc.) system was used to obtain PNDs in the 15-600 nm (mobility diameter) size range at all the 13 sites. The SMPS system includes one differential mobility analyzer (DMA) and one condensation particle counter (CPC). The time resolution of this system was $5 \mathrm{~min}$ and the flow rates of sample and sheath air were 0.3 and $3.0 \mathrm{~L} \mathrm{~min}^{-1}$, respectively. The relative humidity of sample air was kept below $40 \%$ by a silica diffusion dryer within the inlet lines and sheath air cycles. Sizedependent particle losses inside the instruments as well as in the sampling tubes are calculated (Willeke, 1993), and the data are corrected by the obtained correction parameters for each site.

\subsection{Parameterization}

PNDs at each site are parameterized by a multiple log-normal distribution function. Each mode is described by the following function (Seinfeld and Pandis, 1998):

$\frac{\mathrm{d} N_{i}}{\mathrm{~d} \log D_{\mathrm{p}}}=\frac{N_{i}}{\sqrt{2 \pi} \log \sigma_{i}} \exp \left[-\frac{\left(\log D_{\mathrm{p}}-\log \mu_{i}\right)^{2}}{2\left(\log \sigma_{i}\right)^{2}}\right]$,

where $N_{i}, \mu_{i}$, and $\sigma_{i}$ are the total number concentration, mean diameter and geometric mean standard deviation of the distribution of mode $i$, respectively. The task of the fitting program is to minimize the residual part $Q$, which is described as follows:

$Q=\int_{15}^{600} \frac{\left|\mathrm{d} N / \mathrm{d} \log D_{\mathrm{p}}-\sum_{i} \mathrm{~d} N_{i} / \mathrm{d} \log D_{\mathrm{p}}\right|}{\mathrm{d} N / \mathrm{d} \log D_{\mathrm{p}}} \mathrm{d} \log D_{\mathrm{p}}$ 
The growth rate (GR) of newly formed particles and condensational sink (CS) are calculated for NPF events. The CS determines the how quickly of the gaseous molecules can condense onto the pre-existing aerosols and can be calculated by using Eq. (3) (Kulmala et al., 2001, 2012).

$$
\begin{aligned}
\mathrm{CS} & =2 \pi D \int_{15}^{600} D_{\mathrm{p}} \beta_{\mathrm{M}}\left(D_{\mathrm{p}}\right) n\left(D_{\mathrm{p}}\right) \mathrm{d} \log D_{\mathrm{p}} \\
& =2 \pi D \sum_{i} \beta_{\mathrm{M}} D_{\mathrm{p}, i} N_{i}
\end{aligned}
$$

Here $D$ is the diffusion coefficient, $n\left(D_{\mathrm{p}}\right)$ represents the dry particle size distribution function, $\beta_{\mathrm{M}}$ is the transitional correction factor for the mass flux, and $N_{i}$ is the particle number concentration in the size section $i$. The CS value in NPF days is calculated as the mean value, between 09:00 and 12:00 $\mathrm{h}$ (local time), of the day. It should be noted that the CS values calculated here are based on the dry particle number size distributions, which may underestimate the real CS values in ambient humidity.

GR is calculated using the Eq. (4) (Kulmala et al., 2012):

$\mathrm{GR}=\frac{\Delta D_{\mathrm{p}, \mathrm{m}}}{\Delta t}$

where $D_{\mathrm{p}, \mathrm{m}}$ is a mean geometric diameter resulted from the log-normal fitting of the particle number size distribution. The methods for calculating both CS and GR are described by $\mathrm{Wu}$ et al. (2007).

The critical diameter $\left(D_{\mathrm{p}, \text { crit }}\right)$ at which $50 \%$ of the particles are activated at the super saturation $\left(S_{\mathrm{c}}\right)$ can be calculated based on the knowledge of ambient Kappa $(\kappa)$ value expressed by Eq. (5) (Petters and Kreidenweis, 2007).

$\kappa=\frac{4 A^{3}}{27 D_{\mathrm{p}, \mathrm{crit}}^{3} \ln ^{2} S_{\mathrm{c}}}$

$A=\frac{4 \sigma_{\mathrm{s} / a} M_{\mathrm{w}}}{R T \rho_{\mathrm{w}}}$

where $\kappa$ is the hygroscopicity parameter used to model the composition-dependence of the solution water activity; $\sigma_{\mathrm{s} / a}$ is the droplet surface tension (assumed to be that of pure water with $a$ value of $0.0728 \mathrm{~N} \mathrm{~m}^{-2}$ ); $M_{\mathrm{w}}$ is the molecular weight of water; $\rho_{\mathrm{w}}$ is the density of liquid water $\left(\mathrm{g} \mathrm{cm}^{-3}\right)$; $R$ is the universal gas constant $\left(\mathrm{J} \mathrm{mol}^{-1} \mathrm{~K}^{-1}\right)$, and $T$ is the absolute temperature (K).

\section{Results and discussion}

\subsection{Spatial and seasonal variability of PND}

The statistics of PNC in the $15-600 \mathrm{~nm}$ size range are given in Table 2. Average and median PNCs at all sites were in the range of $0.5-2.8 \times 10^{4} \mathrm{~cm}^{-3}$ and $0.4-2.2 \times 10^{4} \mathrm{~cm}^{-3}$, respectively. The median PNC at urban $\left(1.1-2.2 \times 10^{4} \mathrm{~cm}^{-3}\right)$ and regional sites $(0.8$ $1.5 \times 10^{4} \mathrm{~cm}^{-3}$ ) were 2 times larger than those at the coastal/background sites $\left(0.4-0.6 \times 10^{4} \mathrm{~cm}^{-3}\right)$ and during cruise measurement $\left(0.5 \times 10^{4} \mathrm{~cm}^{-3}\right)$. The highest PNCs were observed at $\mathrm{UR}_{\mathrm{u}}$ site due to frequent NPF events, as well as intensive primary emissions, such as coal combustion for local industries, heating supply and residents' use (Li et al., 2008). The average observed PNCs at Chinese urban sites $\left(1.8 \times 10^{4} \mathrm{~cm}^{-3}\right)$ were higher than those in European cities which were reported as $1.6-7.0 \times 10^{3} \mathrm{~cm}^{-3}$ and $1.6 \pm 0.8 \times 10^{4} \mathrm{~cm}^{-3}$ by Borsos et al. (2012) and Kumar et al. (2013a), respectively, suggesting a much larger exposure risks to Chinese population compared with those in European cities. Meanwhile, the average PNCs in low aerosol-loading area (coastal/background sites) in China were still two-fold higher than those in European countries (Asmi et al., 2011a). This suggests that the high aerosol loading in the background areas of China increases the background aerosol concentration.

Peak diameters for measured size distributions are calculated in the range of $24-123 \mathrm{~nm}$ at all sites (Table 2). The peak diameters were found higher at regional sites $(89 \mathrm{~nm}$ on average) than at urban sites ( $69 \mathrm{~nm}$ on average). Aging of particles during their transport from urban to regional area likely leads to the growth of particle diameters (Moffet and Prather, 2009), which leads to the largest particle peak diameters at regional sites despite the frequent NPF events at these sites. Besides, particle emissions from biomass burning in regional areas have diameter larger than $100 \mathrm{~nm}$ (Reid et al., 2005), and may influence the diameter of ambient particles at regional sites. At coastal sites, the peaks of particle size distributions were not as sharp as those seen at other sites (Fig. 2). The PNCs show a wide variation near the peak diameters, as both clean background episodes and polluted episodes caused by transportation occurred in these areas $\mathrm{(Hu}$ et al., 2013).

The median particle size distribution at most of the sites can be fitted into three modes. The peak diameters of these modes were in the range of 132-327 nm for the first mode (which can be roughly recognized as accumulation mode), $59-116 \mathrm{~nm}$ for the second mode (which can be roughly recognized as Aitken mode), and $17-38 \mathrm{~nm}$ for the third mode (which can be roughly recognized as nucleation mode or the second Aitken mode) (Table 2). At $\mathrm{HS}_{\mathrm{r}}, \mathrm{CD}_{\mathrm{r}}$ and $\mathrm{ES}_{\mathrm{s}}$ sites, the fitting exercises give only the first and second modes.

Strong seasonal variations were found at $\mathrm{JX}_{\mathrm{u}}$ and $\mathrm{WX}_{\mathrm{u}}$ sites, where measurements were conducted both in summer and winter. Higher PNCs in nucleation mode and lower PNCs in accumulation mode were observed in summer measurements. 


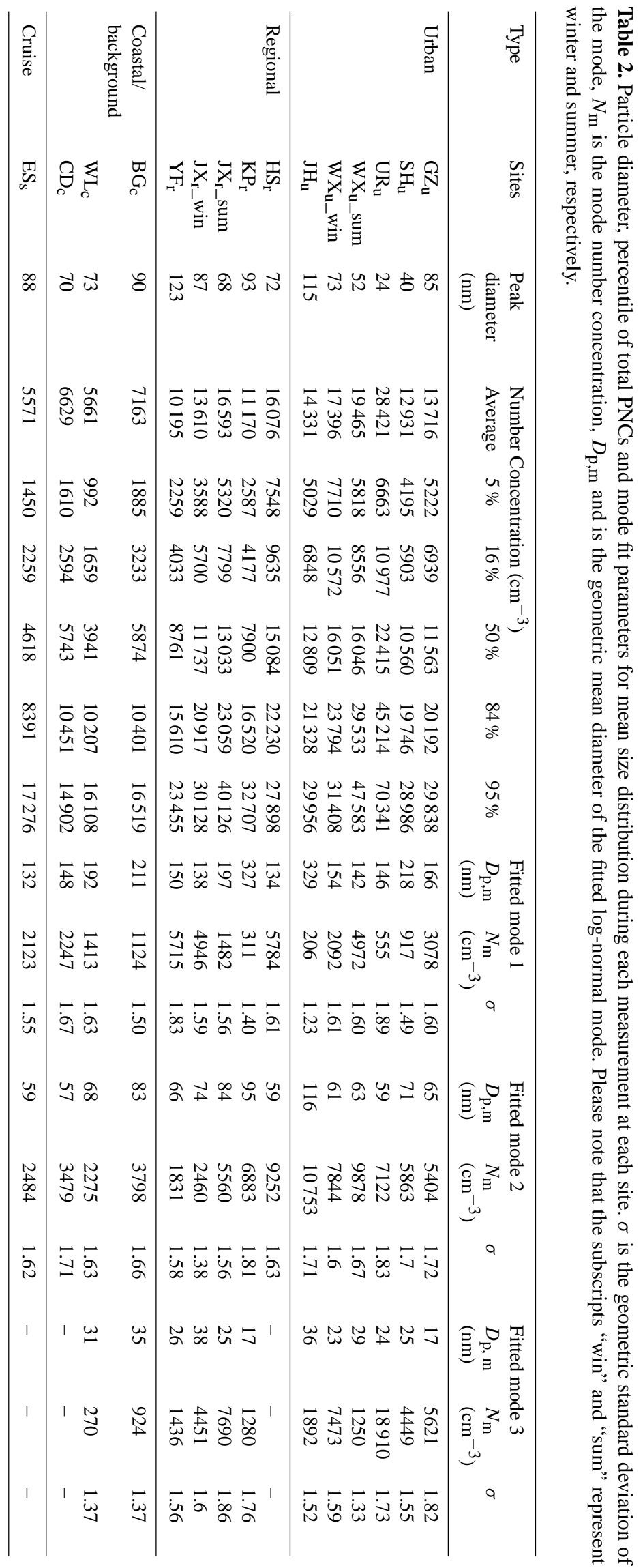




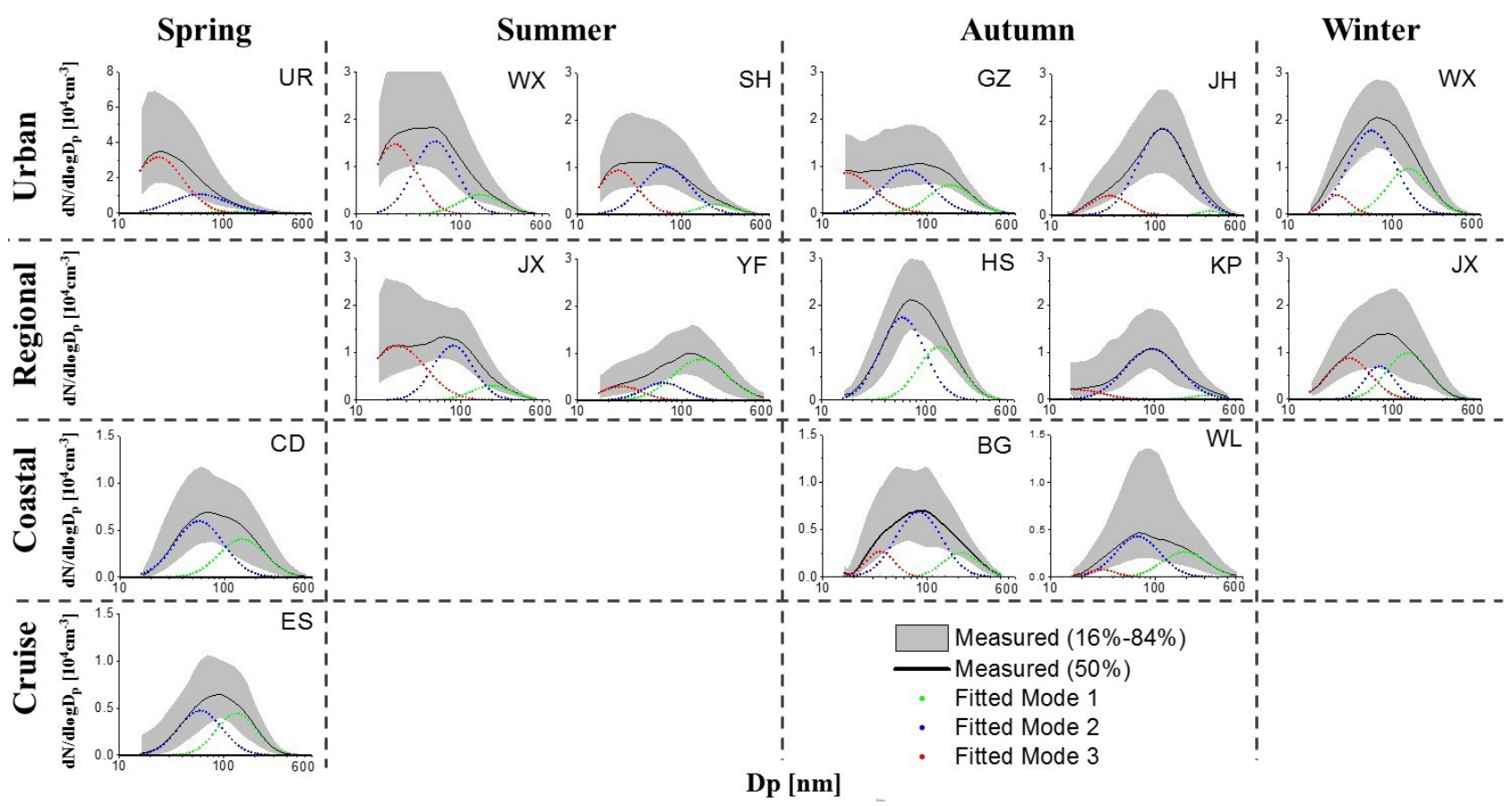

Figure 2. Median distribution (solid black line), 16th and 84th percentile distribution (shaded areas) and fitted modes (green, blue and red scatter dots) at all the measurement sites.

\subsection{Particle number concentration in different size ranges}

The PNCs in the $15-600 \mathrm{~nm}$ range are separated into three different size groups, which are smaller than $25 \mathrm{~nm}\left(N_{15-25}\right)$, $25-100 \mathrm{~nm}\left(N_{25-100}\right)$ and $100-600 \mathrm{~nm}\left(N_{100-600}\right)$. These three size groups are used to represent three modes of nucleation, Aitken, and accumulation, respectively. The number concentration in each mode can be approximated by integrating certain size distribution using the Equation (7):

$N_{a-b}(t)=\int_{a}^{b} n\left(D_{\mathrm{p}}, t\right) \mathrm{d} \log D_{=} p=\sum_{i=a}^{b} n_{i}\left(D_{\mathrm{p}}, t\right)$

where $N_{a-b}(t)$ represents PNCs in the a-b nm range at a certain time interval, $D_{\mathrm{p}}$ is the geometric mean diameter of the size interval, and $n_{i}$ is the measured PNC in a particular size interval $\left(\mathrm{cm}^{-3}\right)$.

As illustrated in Fig. 3, the PNCs in each size range show a good log-normal distribution in most cases, but there are still several major differences among the distribution of PNCs in different size ranges at individual sites. The $N_{100-600}$ at urban and regional sites were much larger than those at coastal sites and during cruise measurement, though these values did not show obvious differences between urban and regional sites, indicating the regional feature of secondary aerosols in the whole region of city clusters. Mean $N_{25-100}$ values appeared to be up to 10-times higher than those in 100$600 \mathrm{~nm}$ size range at urban sites, but no significant differ- ence was found at other sites (Fig. 3), suggesting the emission from road vehicles at urban sites. The distributions of both $N_{15-25}$ and $N_{25-100}$ show a very "narrow" distribution at most studying sites compared with European countries (Asmi et al., 2011a), mainly because there was seldom clean episodes with very few particles in the atmosphere in China. Even if the air mass was coming from the clean remote continental or oceanic region, the new particle formation and high flux of primary particle emission would increase the $N_{15-25}$ and $N_{25-100}$ within a short time (Wu et al., 2008). The PNCs of nucleation mode $\left(N_{15-25}\right)$ particles at coastal sites were lower than those of $N_{100-600}$ and $N_{25-100}$, especially in autumn and winter, suggesting that either the nucleation rate was low, or high proportion of nucleation mode particles coagulated onto the surfaces of larger particles. Besides, a "wide" distribution (Fig. 3c) of $N_{15-25}$ indicates that though the nucleation rate was low most of time at coastal sites, a few NPF events with high concentration in nucleation mode still occurred.

\subsection{Diurnal variation of PND}

Figure 4 shows the diurnal variations of the average PND at all the measurement sites. These figures are sorted by seasons and site types. Diurnal PND at nearly all the measurement sites presents a build-up of high concentration belts with peak diameter between 70 and $150 \mathrm{~nm}$. These belts were much more obvious during night time, when there was neither NPF event nor large amount of primary emissions, and 

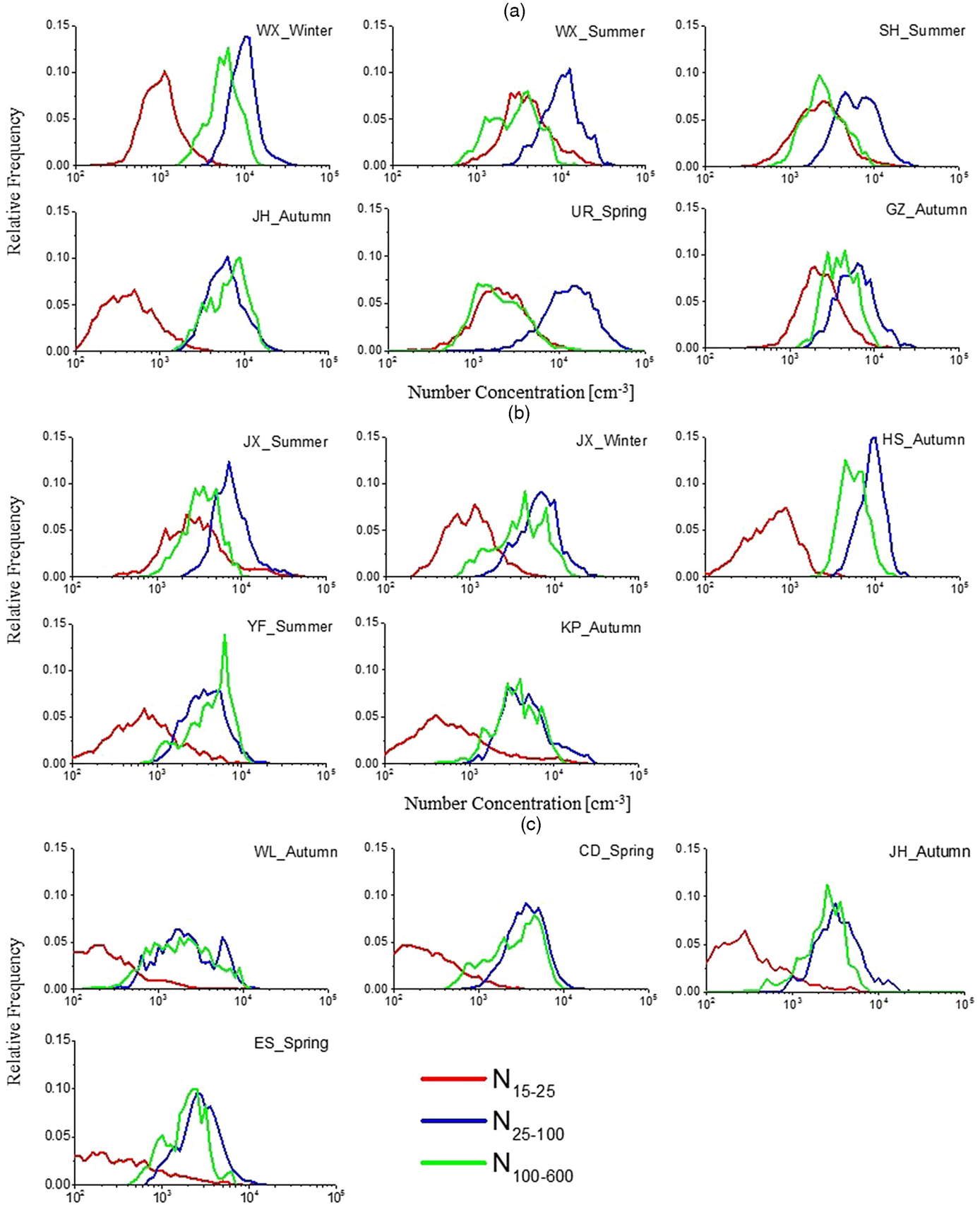

Number Concentration $\left[\mathrm{cm}^{-3}\right]$

Figure 3. Distribution of PNC in different size ranges at (a) urban sites, (b) regional sites, (c) coastal sites and ship measurement. The red, blue and green line represents the distribution of $N_{15-25}, N_{25-100}$ and $N_{100-600}$, respectively.

should be recognized as the accumulation mode. As smaller particles in nucleation mode and Aitken mode have large diffusion coefficient which provides them a large possibility to coagulate onto the surfaces of larger-sized particles, the residence time for particles in the boundary layer are short (Davidson and $\mathrm{Wu}, 1990$ ). On the other hand, accumulation mode particles had much longer atmospheric life and expe- rienced longer aging process in the atmosphere, resulting in the appearance of this accumulation belt. The higher concentration and larger diameter of particles in this accumulation belts may reflect higher degree of aging of ambient particles. For example, at some sites such as $\mathrm{YF}_{\mathrm{r}}$ and $\mathrm{KP}_{\mathrm{r}}$, the peaks of these layers were about 100-120 nm, larger than those at the urban sites of $\mathrm{SH}_{\mathrm{u}}$ and $\mathrm{WX}_{\mathrm{u}}$ (about $80-90 \mathrm{~nm}$ ). Besides, 


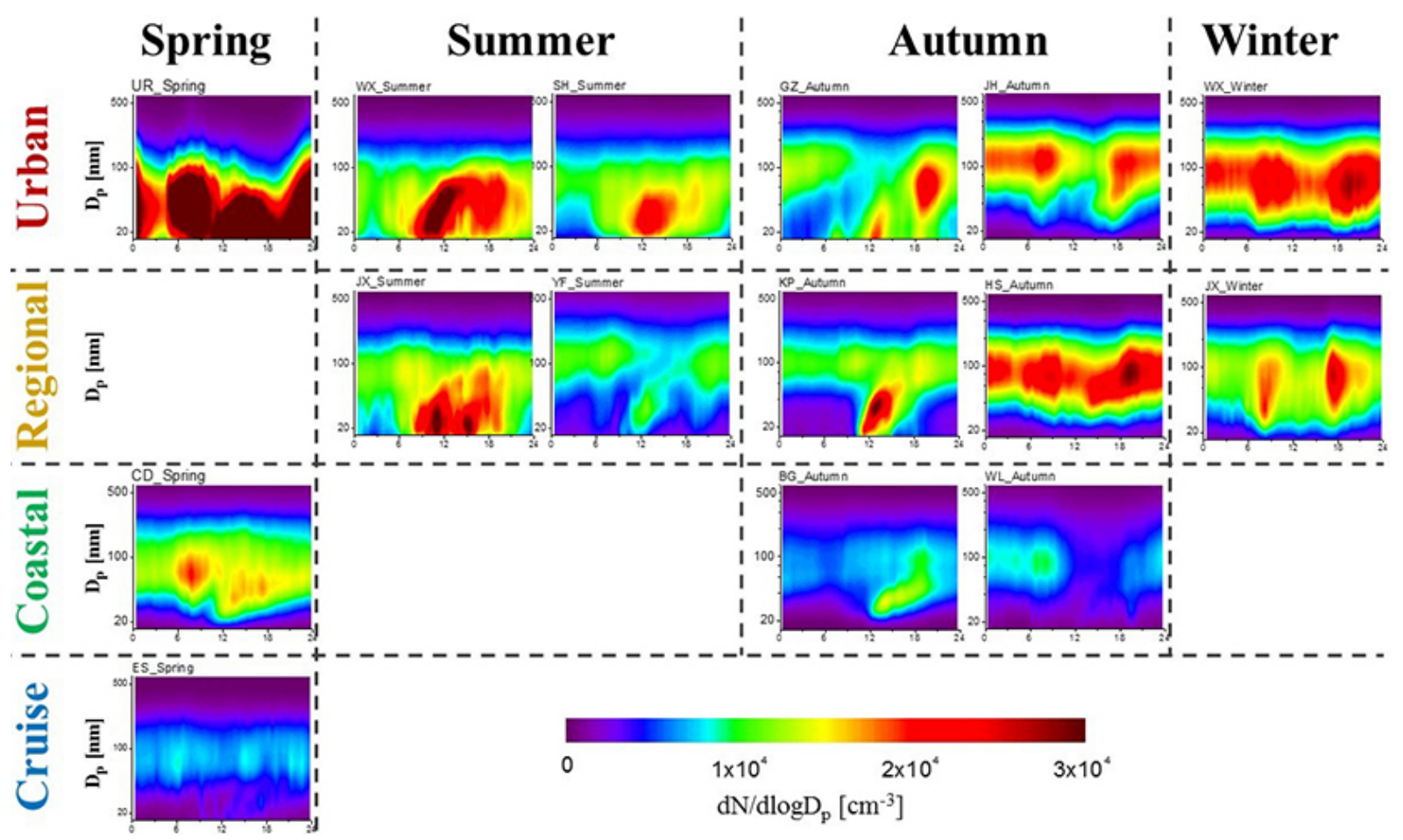

Figure 4. Diurnal variation of PNDs during measurements at different types of sites during different seasons. The color represents $\mathrm{d} N / \mathrm{d} \log D_{\mathrm{p}}\left(\mathrm{cm}^{-3}\right)$. All diurnal variation figures use the same axis and color bar.

particles at all other sites in the three large city groups (see the black circle in Fig. 1) had these high concentration belts, suggesting the regional pollution feature within the whole city group area. In contrast, no such accumulation belt was found at $\mathrm{UR}_{\mathrm{u}}$ site, as the PND at $\mathrm{UR}_{\mathrm{u}}$ site was largely influenced by the large primary emissions and NPF events.

There were large concentrations of nucleation mode particles in the middle of the day at most of studying sites (Fig. 4), showing the contribution of the NPF events to the PNC during the whole measurements. The contributions to the PNCs were much more obvious in summer time due to much more NPF events. On the other hand, the PNCs of nucleation mode were not very high in the middle of the day during all the winter measurements and some of the autumn measurements since there were no NPF events found during these campaigns (Table 3). Compared with urban and regional sites, influence of PNC at coastal/background sites by NPF events was much lower due to the lower concentration of precursor gases (e.g. $\mathrm{SO}_{2}$ ) at these sites.

Besides the peak of NPF events around the noon, there were another two concentration peaks during morning (between 07:00 and 09:00 h) and evening (between 17:00 and 20:00 h) rush hours at most of the urban sites, with the size of the peaks about $30-70 \mathrm{~nm}$. The appearance of these peaks was due to the primary emissions from vehicles as well as the diurnal change of the height of boundary layers (Lin et al., 2009). In the meanwhile, at regional sites there were also two concentration peaks at the same time of day. The difference is that at regional sites the sizes of these peaks were much larger (about 70-150 nm) than at urban sites. This reveals the fact that biomass burning in the regional farmland contribute large amount of primary particles (Huang et al., 2011; Reid et al., 2005). Besides, such morning and evening peaks were not found at coastal sites, confirming that there was no primary emission near these coastal sites.

\subsection{Frequencies and parameters of NPF events}

Obvious NPF events were recognized during most of our measurements. The criterion for discerning NPF events in this study includes three steps. First, there should be a burst of PNC in nucleation mode (below $25 \mathrm{~nm}$ in diameter) (Birmili and Wiedensohler, 2000). Second, primary emitted species, such as black carbon and $\mathrm{CO}$ concentrations should not enhance significantly. Third, the event should last for more than $2 \mathrm{~h}$, with the increase in particle diameter. As the lower cut-off diameter of our measurements $(15 \mathrm{~nm})$ was much larger than the size of nucleation clusters $(1.5-2 \mathrm{~nm})$ (Kulmala et al., 2013), the NPF events might occur 1 to 2 hours before we observed them. Two typical types of NPF events (the "banana" and the "apple", which were classified by Wu et al., 2007) were observed at a number of our sites. The frequencies of NPF events at urban and regional sites $(38 \%)$ were similar to previous studies that focused on the NPF events in some other sites in China (Wu et al., 2007; 
Table 3. Summary of parameters of NPF events at different sites.

\begin{tabular}{|c|c|c|c|c|c|c|}
\hline Site & Type & Country & Season & $\mathrm{CS}\left(\times 10^{-2} \mathrm{~s}^{-1}\right)^{*}$ & $\mathrm{GR}\left(\mathrm{nm} \mathrm{h}^{-1}\right)^{*}$ & Source \\
\hline \multirow[t]{2}{*}{$\mathrm{WX}_{\mathrm{u}}$} & \multirow[t]{2}{*}{ Urban } & \multirow[t]{2}{*}{ China } & Summer & $1.7(0.9-2.8)$ & $10.4(6.2-13.3)$ & This study \\
\hline & & & Winter & None & None & This study \\
\hline $\mathrm{SH}_{\mathrm{u}}$ & Urban & China & Summer & $2.0(1.0-3.3)$ & $8.0(4.2-12)$ & This study \\
\hline $\mathrm{GZ}_{\mathrm{u}}$ & Urban & China & Autumn & $3.9(2.6-5.6)$ & $10.9(7.3-18.1)$ & This study \\
\hline $\mathrm{JH}_{\mathrm{u}}$ & Urban & China & Autumn & None & None & This study \\
\hline $\mathrm{UR}_{\mathrm{u}}$ & Urban & China & Spring & $1.6(1.0-2.6)$ & - & This study \\
\hline Beijing & Urban & China & Whole year & $0.6-6.1$ & $0.1-11.2$ & (Wu et al., 2007) \\
\hline Lanzhou & Suburban & China & Summer & $1.6(0.9-2.4)$ & $4.4(1.4-17.0)$ & (Gao et al., 2011) \\
\hline Mexico City & Urban & Mexico & Spring & - & $0.5-9$ & (Dunn et al., 2004) \\
\hline Tecamac & Suburban & Mexico & Spring & - & $15-40$ & (Iida et al., 2008) \\
\hline New Delhi & Urban & India & Autumn & $5-7$ & $15.0(11.6-18.1)$ & (Monkkonen et al., 2005) \\
\hline Budapest & Urban & Hungary & Whole year & 1.2 & $7.2(2.0-13.3)$ & (Salma et al., 2011) \\
\hline Po Valley & Urban & Italy & Whole year & $1.0(0.4-1.8)$ & $6.8(4.2-8.0)$ & (Hamed et al., 2007) \\
\hline \multirow[t]{2}{*}{$\mathrm{J} \mathrm{X}_{\mathrm{r}}$} & \multirow[t]{2}{*}{ Regional } & \multirow[t]{2}{*}{ China } & Summer & $2.2(1.1-4.1)$ & $13.6(7.9-19.6)$ & This study \\
\hline & & & Winter & None & None & This study \\
\hline $\mathrm{YF}_{\mathrm{r}}$ & Regional & China & Summer & $2.7(0.5-5.3)$ & $12.3(8.6-21)$ & This study \\
\hline $\mathrm{HS}_{\mathrm{r}}$ & Regional & China & Autumn & None & None & This study \\
\hline $\mathrm{KP}_{\mathrm{r}}$ & Regional & China & Autumn & $2.5(0.3-8.6)$ & $7.4(3.2-13.5)$ & This study \\
\hline Back-garden & Regional & China & Summer & $2.6(2.3-3.3)$ & $12.1(4.0-22.7)$ & (Yue et al., 2013) \\
\hline Xinken & Regional & China & Autumn & - & $8.3(2.2-19.8)$ & (Liu et al., 2008) \\
\hline K-puszta & Rural & Hungary & Summer & $0.5(0.06-1.4)$ & $6.1(2.2-14.4)$ & (Yli-Juuti et al., 2009) \\
\hline $\mathrm{WL}_{\mathrm{c}}$ & Coastal & China & Autumn & 2.6 & 7.5 & This study \\
\hline $\mathrm{BG}_{\mathrm{c}}$ & Coastal & China & Autumn & $1.4(1.0-1.8)$ & $4.5(3.2-7.5)$ & This study \\
\hline $\mathrm{CD}_{\mathrm{c}}$ & Coastal & China & Spring & $2.0(1.9-2.1)$ & $5.7(4.5-6.8)$ & This study \\
\hline $\mathrm{ES}_{\mathrm{S}}$ & Marine & China & Spring & $0.9(0.8-1.1)$ & $2.8(1.6-3.9)$ & This study \\
\hline Shangdianzi & Background & China & Whole year & 2 & $4.3(0.3-14.5)$ & (Shen et al., 2011) \\
\hline Yellow Sea & Marine & China & Spring & - & 3.4 & (Lin et al., 2007) \\
\hline Foresthill & Remote & American & Winter & - & $2-8$ & (Creamean et al., 2011) \\
\hline Hyytiala & Forest & Finland & Whole year & $0.2(0.04-0.8)$ & $3.0(0.2-12)$ & (Maso et al., 2005) \\
\hline
\end{tabular}

* The values outside the bracket represent the average CS or GR; the values inside the bracket represent the maximum and minimum CS or GR; "none" means that there is no NPF events found in the whole measurement; "-" means that the GR value can not be calculated (only for the site of UR $\mathrm{u}_{\mathrm{u}}$ ), or there is no such information in the reference paper.

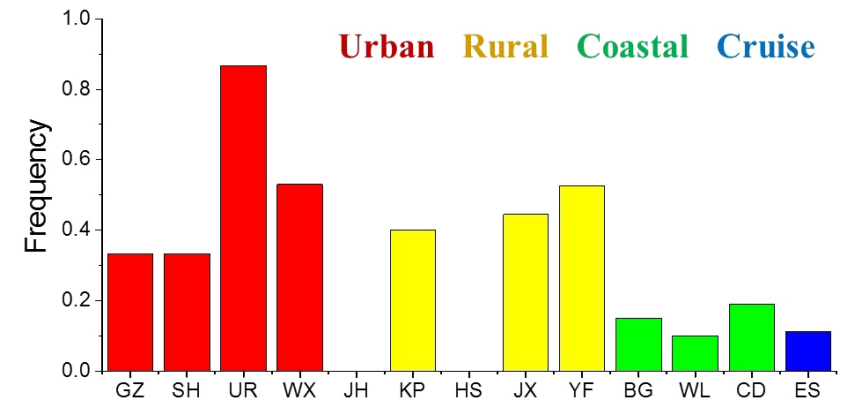

Figure 5. Frequencies of NPF events at different sites. The color of red, yellow, green and blue represent the site type of urban, rural, coastal and cruise, respectively.

Yue et al., 2013) and were much higher than at coastal sites and events in some other sites in China (Fig. 5).

Sulfuric acid is a well-known precursor for nucleation (Boy et al., 2005; Zhang, 2010; Yue et al., 2010; Andreae,
2013). High concentrations of $\mathrm{SO}_{2}$ and $\mathrm{OH}$ provide strong source of sulfuric acid at urban and regional sites, and promote the NPF events. On the other hand, the aerosol loading in the ambient atmosphere acts as the condensation and coagulation sink and thus restrains the NPF event. Though the high concentration of pre-existing particles can hinder the NPF in urban and regional areas, there will also be high precursor concentration (such as $\mathrm{SO}_{2}$, and VOCs) and strong oxidation (performed as high $\mathrm{O}_{3}$ and $\mathrm{OH}$ radical concentration) in these areas, which will favor the NPF. At urban and regional sites in our study, the high precursor concentration and strong oxidation may play a more crucial role than the high concentration of pre-existing particles, leading to the high frequency of NPF events. On the other hand, in the clean coastal area in China, concentrations of precursors as well as the particles are not as high as in urban area as both gases and particles will be dilute during the transport from polluted region to clean coastal area. Moreover, unlike the particles, the gaseous precursors may also undergo 
continually atmospheric oxidation and transform into particle phase during the transport, which makes the reduction of gaseous precursors larger than the reduction of particles, resulting in fewer NPF events at coastal sites. Besides, other reasons such as meteorological conditions might also affect the frequency of NPF events at diversified sites. In polluted areas, the NPF events are often expected to occur since the air mass is coming from the clean continental background and is not greatly influenced by the polluted urban air (Wu et al., 2007). At coastal sites, however, no NPF events were noted when the air mass was coming from the ocean side with clean air, as this cleaner air mass was not carrying enough NPF precursors such as $\mathrm{H}_{2} \mathrm{SO}_{4}$ or low-volatile VOCs to favor the nucleation events. This is substantiated by the fact that $\mathrm{SO}_{2}$ concentrations in the air coming from ocean side were much lower than those coming from the continent (e.g., at $\mathrm{BG}_{\mathrm{c}}$ site, average $\mathrm{SO}_{2}$ concentration in the air mass from ocean and continent were $1.4 \mathrm{ppbv}$ and $2.8 \mathrm{ppbv}$, respectively) and supported by other studies at coastal site (Yu et al., 2014).

The CS values of NPF events are calculated as the mean CS value, between 09:00 to 12:00 h (local time), of the day (Eq. 3). In general, CS in all NPF days were in the range of $0.9-5.6 \times 10^{-2} \mathrm{~s}^{-1}$ at urban sites, $0.3-8.6 \times 10^{-2} \mathrm{~s}^{-1}$ at regional sites, $1.0-2.6 \times 10^{-2} \mathrm{~s}^{-1}$ at coastal/background sites and $0.8-1.1 \times 10^{-2} \mathrm{~s}^{-1}$ during cruise measurement (see Table 3). The upper limits of CS at urban and regional sites were far larger compared with those at coastal/background sites and during cruise measurement and at other sites in western countries (Table 3), which further confirms the fact that NPF events can occur under high aerosol loading in polluted areas in China (Wu et al., 2007). On the other hand, the lower limit of CS at different sites showed no obvious difference, indicating that there are "clean case" NPF events even in these polluted urban areas (Wu et al., 2007).

The GRs of newly formed particles (calculated from $15 \mathrm{~nm}$ to $30 \mathrm{~nm}$ ) ranged from 4.2 to $18.1 \mathrm{~nm} \mathrm{~h}^{-1}$ at urban sites, 3.2 to $21 \mathrm{~nm} \mathrm{~h}^{-1}$ at regional sites, and 1.6 to $7.5 \mathrm{~nm} \mathrm{~h}^{-1}$ at both coastal sites and during cruise measurement (Table 3 ). The highest GR was found at $\mathrm{YF}_{\mathrm{r}}$ site (regional) with value of $21 \mathrm{~nm} \mathrm{~h}^{-1}$. Average GRs at urban and regional sites were about twice those at coastal sites and during cruise measurement (Table 3), indicating that the higher concentrations of gaseous precursors in the polluted areas not only favor the formation of particles, but also accelerate the growth rate as long as the nucleation particles are formed.

Both the CS and GR results in our study are comparable to other studies performed in Beijing (Wu et al., 2007), Backgarden (Yue et al., 2013), and Xinken (Liu et al., 2008), in China. CS values in our study are generally higher than those at European and American sites and smaller than those at some sites in developing countries, such as New Delhi (see Table 3). The GR values show no obvious differences between China and other countries (both in developed and developing countries) at the same site types (see Table 3 ).

\subsection{Evaluation of the contribution of NPF to potential $\mathbf{C C N}$}

The basic idea to estimate the production of potential CCN from NPF events is based on the assumption that particles larger than a certain diameter could be served as CCN. As the newly formed particles consist mainly ammonium sulfate and secondary organics (Yue et al., 2010) and primary emission particles contain a lot of black carbon and hydrophobic organics (Medalia and Rivin, 1982; Reid et al., 2005), the $\kappa$ value for newly formed particles and primary emission particles may be of large difference. Some previous studies in China have concluded that the average $\kappa$ value of all ambient particles is about 0.3 for many environments in China (Gunthe et al., 2011; Yue et al., 2010; Rose et al., 2010), but few has provided the $\kappa$ value of newly formed particles in the atmosphere. In this study, the hygroscopicity parameter $\kappa$ for the newly formed particles is taken as 0.43 at about $100 \mathrm{~nm}$ based on the assumption of one third of chemical components of these particles are organics and others were inorganics (Gunthe et al., 2011; Yue et al., 2010). Therefore, the only task left is to achieve the PND of newly formed particles.

In this study, mode fitting method is used to distinguish the newly formed particles from others. Diurnal half-hourly average PND data are used for the log-normal fitting. A total of three (or four) lognormal modes are achieved in the fitness exercise (see Eq. 1) on the PND data. These include up to two NPF modes (with initial diameter about 15-20 nm, which may grow up to $50 \mathrm{~nm}$ later), one Aitken mode (40-100 nm) as well as one accumulation mode $(100-500 \mathrm{~nm})$. Figure 6 illustrates an example of the mode fitting result at the site of $\mathrm{KP}_{\mathrm{r}}$, which is a typical regional site with high frequency of NPF events. Half-hourly fitting results in the afternoon from 11:00 to $16: 00 \mathrm{~h}$ at $\mathrm{KP}_{\mathrm{r}}$ site with two NPF modes and two pre-existing modes are shown in Fig. 6. At the site of $\mathrm{KP}_{\mathrm{r}}$, NPF events were observed to occur between mainly between 09:00 and 11:00 h every day, resulting in a sharp and narrow nucleation mode peak at about $19 \mathrm{~nm}$ at $11: 00 \mathrm{~h}$ (Fig. 6). In the following 5 hours, the peak diameter of NPF mode gradually grew from 19 to $50 \mathrm{~nm}$, with the concentration of NPF mode decreasing from 7500 to $5000 \mathrm{~cm}^{-3}$ at the same time. Furthermore, when the peak diameters of these lognormal distribution NPF modes reached $50 \mathrm{~nm}$, there would be a large amount of particles with diameter exceed $80 \mathrm{~nm}$ or even $100 \mathrm{~nm}$. These particles were large enough to possibly act as CCN under a certain $S_{\mathrm{c}}$. The contribution of NPF to potential CCN production can then be calculated by integrating the distribution of the NPF mode particle with diameter larger than $D_{\mathrm{p} \text {, crit }}$. As it is challenging to extract NPF mode when the NPF peaks are submerged in the size distribution of ambient particles, in order to achieve accurate fitness results, prominent NPF peak in the size distribution is required. Therefore, our subsequent discussions focused on the time period from 13:00 to 17:00 $\mathrm{h}$ in the afternoon, as the time is neither too early for the formation of new particles, nor too 


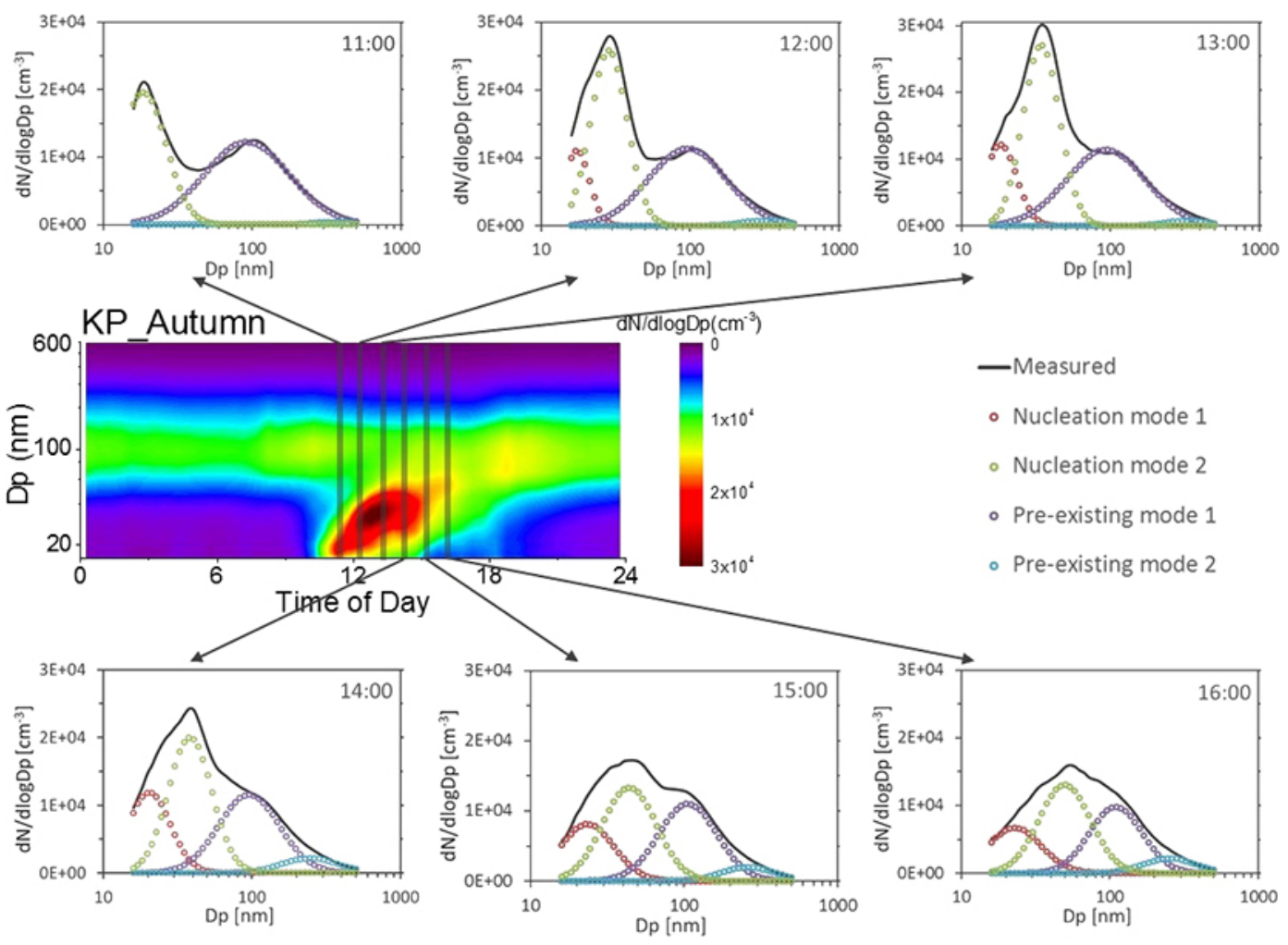

Figure 6. Lognormal fitting result of diurnal average PND at $\mathrm{KP}_{\mathrm{r}}$ site. The six line and symbol pictures show the mode fit results for the diurnal variation from 11:00 to 16:00 at $\mathrm{KP}_{\mathrm{r}}$ site. Totally two nucleation modes and two pre-existing modes are found by mode fitting.

late for primary emission to perform a dominate role in the ambient PND.

The contributions of NPF events and growth to potential CCN concentration in all measurements are calculated through this approach. Results of this exercise are illustrated in Table 4. Two values of super saturations are assumed here as 0.5 and $0.2 \%$, with critical diameter of $50 \mathrm{~nm}$ and $91 \mathrm{~nm}$ for newly formed particles, and $60 \mathrm{~nm}$ and $100 \mathrm{~nm}$ for other particles, respectively. Contributions of NPF to potential CCN concentration varied greatly during different measurements, ranging from 0 to $66 \%$ when $S_{\mathrm{c}}$ is 0.5 , and 0 to $24 \%$ when $S_{\mathrm{c}}$ is 0.2 (Table 4). The highest values were found in the summer at $\mathrm{WX}_{\mathrm{u}}$ site. During summertime, the average contributions values at urban and regional sites were $50 \%$ $\left(S_{\mathrm{c}}=0.5\right)$ and $18 \%\left(S_{\mathrm{c}}=0.2\right)$, which were much higher than those in other seasons. The strong oxidation condition in summer favors the formation of new NPF as well as the growth of newly formed particles, accelerating the newly formed particles to perform as CCN. On the contrary, the contribution is $0 \%$ during two winter measurements, as no NPF events were observed during these two measurements.

Weighted average contributions for different size types are roughly calculated. Annual average contribution of NPF to $\mathrm{CCN}$ at urban, regional and coastal sites were found to be $33 \%, 19 \%, 7 \%$ (at $S_{\mathrm{c}}=0.5$ ), and $11 \%, 6 \%, 0 \%$ (at $\left.S_{\mathrm{c}}=0.2\right)$, respectively. Good correlation $\left(R^{2}=0.7\right)$ between growth rate of NPF and contribution to $\mathrm{CCN}$ among all sties was found, indicating that growth rates of NPF events are the decisive factor in the conversion of newly formed particle to possible CCN (Yue et al., 2011).

Although there were two NPF events during the cruise measurement, no contribution to $\mathrm{CCN}$ concentration was found by these NPF events, because the diameter of these secondary particles did not meet the critical diameter for CCN. Zhang et al. (2012) demonstrated that NPF in marine environment is not likely to produce particles of the size of CCN. Our study further confirms that the NPF events show little impact on the concentration of $\mathrm{CCN}$ in the marine area near polluted continent. It may need more than one day for the newly formed particles to perform as $\mathrm{CCN}$.

In previous studies, people always use the $\mathrm{CCN}$ concentration enhancement factor to describe the contribution of NPF events to corresponding CCN (Yue et al., 2011; Kuang et al., 2009; Lihavainen et al., 2003). It is obtained by dividing the concentration of CCN-sized particles after a NPF event by that prior to the event. The average $\mathrm{CCN}$ enhancement factors after the NPF events at $S_{\mathrm{c}}=0.2\left(D_{\mathrm{p}, \text { crit }}=100 \mathrm{~nm}\right)$ were calculated to be 1.5 at a remote site in Northern Finland ( $\mathrm{Li}-$ havainen et al., 2003) and in the range of 1.5-2.5 in Beijing (Yue et al., 2011). Similar conclusion was obtained in Botsalano, but with great seasonal variation (Laakso et al., 2013). The factors in these studies are higher than in our 
Table 4. Summary of contribution of NPF events to potential CCN during the time between 14:00 to 17:00 LT in all measurements.

\begin{tabular}{lrr|rr|rr|rr}
\hline & & Spring & & Summer & & Autumn & Winter \\
& $S_{\mathrm{c}}=0.5$ & $S_{\mathrm{c}}=0.2$ & $S_{\mathrm{c}}=0.5$ & $S_{\mathrm{c}}=0.2$ & $S_{\mathrm{c}}=0.5$ & $S_{\mathrm{c}}=0.2$ & $S_{\mathrm{c}}=0.5$ & $S_{\mathrm{c}}=0.2$ \\
\hline Urban & $33 \%$ & $6 \%$ & $66 \%$ & $26 \%$ & $31 \%$ & $9 \%$ & $0 \%$ & $0 \%$ \\
& & & & & $0 \%$ & $0 \%$ & & $0 \%$ \\
Regional & - & - & $57 \%$ & $23 \%$ & $30 \%$ & $6 \%$ & $0 \%$ & $0 \%$ \\
& & & $28 \%$ & $5 \%$ & $0 \%$ & $0 \%$ & & - \\
Coastal & $10 \%$ & $<1 \%$ & & - & $8 \%$ & $<1 \%$ & - & - \\
Cruise & $<1 \%$ & $<1 \%$ & - & - & $5 \%$ & $<1 \%$ & - & - \\
\hline
\end{tabular}

"--" represents that there is no measurement at that type of sites in the certain season; " $0 \%$ " represent that there is no NPF event found in the measurement; " $<1 \%$ " represent that there are NPF events found in the measurement, but the relative contributions of these NPF events to the total $\mathrm{CCN}$ concentration are smaller than $1 \%$.

study because they only considered NPF days. The values would be much lower and similar to our result if the enhancements were multiplied by the frequencies of NPF events. Besides, the method used in these studies did not consider the influence of primary emissions and change of boundary layer height on CCN concentration (Laakso et al., 2013) and thus may overestimate the enhancements. The mode fit method used in this study can exclude the influence of primary emission by adding one Aitken mode in the fitting result and therefore can provide more accurate contribution. However, there are still some uncertainties and limitations in this study. First, we can only calculate the contribution to $\mathrm{CCN}$ production by the NPF event in the same day. Some of the preexisting particles before NPF events may also come from the NPF in previous days, but these can only be recognized as pre-existing particles rather than NPF particles through our approach. This is likely to result in underestimation of the contribution. Second, even though our method has its advantage distinguishing the nucleation particles from non-NPF particles, some non-NPF particles may have a chance to be recognized as nucleation particle when we perform the processing of diurnal average PNCs, which may lead to overestimation of results. Third, as discussed above, the approach requires very clear NPF peaks in the size distributions in order to achieve accurate fitness results. So the focusing time period is constrained between 14:00 and 17:00 h, when the NPF mode is clear and evening rush hour has not come. The contribution in the following hours or the following days cannot be precisely calculated though this approach. As it is crucial to evaluate the contribution of NPF events to CCN production in the following days, more studies on this field are needed in the future. Nevertheless, based on field measurements, our work provides annual and seasonal average contribution of NPF events to CCN production for the first time in diversified Chinese atmosphere. The estimation of contribution of NPF events to corresponding $\mathrm{CCN}$ might be particularly useful for the validation of global climate models.

\section{Summary and conclusions}

This paper presents size-resolved measurements of submicron aerosol in the $15-600 \mathrm{~nm}$ size range during the 15 individual field campaigns, taken between 2007 and 2011, at thirteen different sites in China. These sites include five urban sites, four regional sites, three coastal/background sites and one ship cruise measurement, and are mainly located within the three largest city clusters of China.

The particle number size distributions are fitted into three modes (nucleation, Aitken, accumulation) at most of the sites. The median PNC at urban (1.1-2.2 $\left.\times 10^{4} \mathrm{~cm}^{-3}\right)$ and regional sites $\left(0.8-1.5 \times 10^{4} \mathrm{~cm}^{-3}\right)$ were two-times larger than those at coastal and background $\left(0.4-0.6 \times 10^{4} \mathrm{~cm}^{-3}\right)$ sites and during cruise measurement $\left(0.5 \times 10^{4} \mathrm{~cm}^{-3}\right)$.

Primary emission from road vehicles as well as regional biomass burning appears to have a large contribution to the ambient PNCs. High emissions from road vehicles at urban sites resulted in up to 10-times higher $N_{25-100}$ than those of $N_{100-600}$. PNCs in both size ranges were nearly identical at all other sites. Vehicular emissions at urban sites and biomass burning emission at regional sites led to two concentration peaks in the early morning and evening hours.

Regional secondary aerosol pollution is a main feature for the submicron aerosol pollution in China. No obvious differences in the $N_{100-600}$ particles were observed between urban and regional sites. Diurnal variations show a build-up of high concentration accumulation belt at all the regional sites.

The occurrence frequencies of the NPF events in high aerosol-loading environment of China were found to be higher than those in less aerosol-loading environments. High gaseous precursors and strong oxidation at urban and regional sites not only favor the formation of particles, but also accelerate the growth rate after the nucleation mode particles are formed. The average GR of nucleation mode particles were $8.0-10.9 \mathrm{~nm} \mathrm{~h}^{-1}$ at urban sites, $7.4-13.6 \mathrm{~nm} \mathrm{~h}^{-1}$ at regional sites and $2.8-7.5 \mathrm{~nm} \mathrm{~h}^{-1}$ at coastal sites and during cruise measurement. The NPF events in the less 
aerosol-loading environment were found to be greatly influenced by pollutant transport.

Average contributions of NPF events to potential CCN are calculated in this study. Contributions of NPF events to potential $\mathrm{CCN}$ at 0.2 super-saturation in the afternoon of all measurement days were $11 \%$ and $6 \%$ at urban sites and regional sites, respectively. On the other hand, NPF events at coastal sites and during cruise measurement had little impact on potential $\mathrm{CCN}$.

Our study presents a unique data set of aerosol size distributions and general concepts of the features of submicron particle pollution along with the fundamental drivers of particulate pollution in China. Besides, our estimation of contribution of NPF events to corresponding CCN might be particularly useful for the validation of global climate models.

\section{The Supplement related to this article is available online at doi:10.5194/acp-14-10249-2014-supplement.}

Acknowledgements. This work was supported by the National Natural Science Foundation of China (21025728 and 21190052 ), the National Basic Research Program of China (2013CB228503) and the China Ministry of Environmental Protection's Special Funds for Scientific Research on Public Welfare (201009002). Prashant Kumar, Jianfei Peng and Min Hu thank the University of Surrey's International Relations Office for the Santander Postgraduate Mobility Award that helped Jianfei Peng to visit University of Surrey, UK, to develop this research article collaboratively.

Edited by: V.-M. Kerminen

\section{References}

Andreae, M. O.: The Aerosol Nucleation Puzzle, Science, 339, 911912, doi:10.1126/science.1233798, 2013.

Asmi, A., Wiedensohler, A., Laj, P., Fjaeraa, A. M., Sellegri, K., Birmili, W., Weingartner, E., Baltensperger, U., Zdimal, V., Zikova, N., Putaud, J. P., Marinoni, A., Tunved, P., Hansson, H. C., Fiebig, M., Kivekäs, N., Lihavainen, H., Asmi, E., Ulevicius, V., Aalto, P. P., Swietlicki, E., Kristensson, A., Mihalopoulos, N., Kalivitis, N., Kalapov, I., Kiss, G., de Leeuw, G., Henzing, B., Harrison, R. M., Beddows, D., O’Dowd, C., Jennings, S. G., Flentje, H., Weinhold, K., Meinhardt, F., Ries, L., Kulmala, M.: Number size distributions and seasonality of submicron particles in Europe 2008-2009, Atmos. Chem. Phys., 11, 5505-5538, doi:10.5194/acp-11-5505-2011, 2011a.

Asmi, E., Kivekäs, N., Kerminen, V.-M., Komppula, M., Hyvärinen, A.-P., Hatakka, J., Viisanen, Y., and Lihavainen, H.: Secondary new particle formation in Northern Finland Pallas site between the years 2000 and 2010, Atmos. Chem. Phys., 11, 1295912972, doi:10.5194/acp-11-12959-2011, 2011 b.

Bigi, A. and Ghermandi, G.: Particle Number Size Distribution and Weight Concentration of Background Urban Aerosol in a Po Valley Site, Water Air Soil Poll., 220, 265-278, doi:10.1007/s11270011-0752-6, 2011.
Borsos, T., Rimnacova, D., Zdimal, V., Smolik, J., Wagner, Z., Weidinger, T., Burkart, J., Steiner, G., Reischl, G., Hitzenberger, R., Schwarz, J., and Salma, I.: Comparison of particulate number concentrations in three Central European capital cities, Sci. Total Environ., 433, 418-426, 2012.

Boy, M., Kulmala, M., Ruuskanen, T. M., Pihlatie, M., Reissell, A., Aalto, P. P., Keronen, P., Dal Maso, M., Hellen, H., Hakola, H., Jansson, R., Hanke, M., and Arnold, F.: Sulphuric acid closure and contribution to nucleation mode particle growth, Atmos. Chem. Phys., 5, 863-878, doi:10.5194/acp-5-863-2005, 2005.

Buseck, P. R., and Adachi, K.: Nanoparticles in the Atmosphere, Elements, 4, 389-394, doi:10.2113/gselements.4.6.389, 2008.

Creamean, J. M., Ault, A. P., Ten Hoeve, J. E., Jacobson, M. Z., Roberts, G. C., and Prather, K. A.: Measurements of Aerosol Chemistry during New Particle Formation Events at a Remote Rural Mountain Site, Environ. Sci. Technol., 45, 8208-8216, 2011.

Dal Maso, M., Kulmala, M., Riipinen, I., Wagner, R., Hussein, T., Aalto, P. P., and Lehtinen, K. E. J.: Formation and growth of fresh atmospheric aerosols: eight years of aerosol size distribution data from SMEAR II, Hyytiala, Finland, Boreal Environ. Res., 10, 323-336, 2005.

Davidson, C. I., and Wu, Y. L.: Dry deposition of particles and vapors, in Acid Precipitation, Vol. 3, S. E. Lindberg, A. L. Page, and S. A. Norton, eds., Springer-Verlag, Berlin, pp. 103-209, 1990.

Du, J. F., Cheng, T. T., Zhang, M., Chen, J. M., He, Q. S., Wang, X. M., Zhang, R. J., Tao, J., Huang, G. H., Li, X., and Zha, S. P.: Aerosol Size Spectra and Particle Formation Events at Urban Shanghai in Eastern China, Aerosol Air Qual. Res., 12, 13621372, 2012.

Dunn, M. J., Jimenez, J. L., Baumgardner, D., Castro, T., McMurry, P. H., and Smith, J. N.: Measurements of Mexico City nanoparticle size distributions: Observations of new particle formation and growth, Geophys. Res. Lett., 31, L10102, doi:10.1029/2004GL019483, 2004.

Dusek, U., Frank, G. P., Hildebrandt, L., Curtius, J., Schneider, J., Walter, S., Chand, D., Drewnick, F., Hings, S., Jung, D., Borrmann, S., and Andreae, M. O.: Size Matters More Than Chemistry for Cloud-Nucleating Ability of Aerosol Particles, Science, 312, 1375-1378, doi:10.1126/science.1125261, 2006.

Gao, J., Chai, F. H., Wang, T., and Wang, W. X.: Particle number size distribution and new particle formation (NPF) in Lanzhou, Western China, Particuology, 9, 611-618, 2011.

Gong, Z. H., Lan, Z. J., Xue, L., Zeng, L. W., He, L. Y., and Huang, $X$. F.: Characterization of submicron aerosols in the urban outflow of the central Pearl River Delta region of China, Frontiers of Environmental Science \& Engineering, 6, 725-733, 2012.

Gunthe, S. S., Rose, D., Su, H., Garland, R. M., Achtert, P., Nowak, A., Wiedensohler, A., Kuwata, M., Takegawa, N., Kondo, Y., Hu, M., Shao, M., Zhu, T., Andreae, M. O., and Pöschl, U.: Cloud condensation nuclei (CCN) from fresh and aged air pollution in the megacity region of Beijing, Atmos. Chem. Phys., 11, 1102311039, doi:10.5194/acp-11-11023-2011, 2011.

Guo, S., Hu, M., Wang, Z. B., Slanina, J., and Zhao, Y. L.: Sizeresolved aerosol water-soluble ionic compositions in the summer of Beijing: implication of regional secondary formation, Atmos. Chem. Phys., 10, 947-959, doi:10.5194/acp-10-947-2010, 2010.

Hamed, A., Joutsensaari, J., Mikkonen, S., Sogacheva, L., Dal Maso, M., Kulmala, M., Cavalli, F., Fuzzi, S., Fac- 
chini, M. C., Decesari, S., Mircea, M., Lehtinen, K. E. J., and Laaksonen, A.: Nucleation and growth of new particles in Po Valley, Italy, Atmos. Chem. Phys., 7, 355-376, doi:10.5194/acp7-355-2007, 2007.

Harrison, R. M., Beddows, D. C. S., and Dall'Osto, M.: PMF Analysis of Wide-Range Particle Size Spectra Collected on a Major Highway, Environ. Sci. Technol., 45, 5522-5528 2011.

Heal, M. R., Kumar, P., and Harrison, R. M.: Particles, air quality, policy and health, Chem. Soc. Rev., 41, 6606-6630, 2012.

Herrmann, E., Ding, A. J., Kerminen, V.-M., Petäjá, T., Yang, X. Q., Sun, J. N., Qi, X. M., Manninen, H., Hakala, J., Nieminen, T., Aalto, P. P., Kulmala, M., and Fu, C. B.: Aerosols and nucleation in eastern China: first insights from the new SORPES-NJU station, Atmos. Chem. Phys., 14, 2169-2183, doi:10.5194/acp14-2169-2014, 2014.

Hu, W. W., Hu, M., Yuan, B., Jimenez, J. L., Tang, Q., Peng, J. F., Hu, W., Shao, M., Wang, M., Zeng, L. M., Wu, Y. S., Gong, Z. H., Huang, X. F., and He, L. Y.: Insights on organic aerosol aging and the influence of coal combustion at a regional receptor site of central eastern China, Atmos. Chem. Phys., 13, 10095-10112, doi:10.5194/acp-13-10095-2013, 2013.

Huang, X.-F., He, L.-Y., Hu, M., Canagaratna, M. R., Kroll, J. H., Ng, N. L., Zhang, Y.-H., Lin, Y., Xue, L., Sun, T.-L., Liu, X.-G., Shao, M., Jayne, J. T., and Worsnop, D. R.: Characterization of submicron aerosols at a rural site in Pearl River Delta of China using an Aerodyne High-Resolution Aerosol Mass Spectrometer, Atmos. Chem. Phys., 11, 1865-1877, doi:10.5194/acp-11-18652011, 2011.

Huang, X.-F., He, L.-Y., Xue, L., Sun, T.-L., Zeng, L.-W., Gong, Z.-H., Hu, M., and Zhu, T.: Highly time-resolved chemical characterization of atmospheric fine particles during 2010 Shanghai World Expo, Atmos. Chem. Phys., 12, 4897-4907, doi:10.5194/acp-12-4897-2012, 2012.

Iida, K., Stolzenburg, M. R., McMurry, P. H., and Smith, J. N.: Estimating nanoparticle growth rates from sizedependent charged fractions: Analysis of new particle formation events in Mexico City, J. Geophys. Res., 113, D05207 doi:10.1029/2007JD009260, 2008.

IPCC (Intergovernmental Panel on Climate Change): Climate Change 2007: The Physical Science Basis. Contribution of Working Group I to the Fourth Assessment, Report of the Intergovernmental Panel on Climate Change, Cambridge University Press, Cambridge, United Kingdom, and New York, NY, USA..

Kerminen, V.-M., Paramonov, M., Anttila, T., Riipinen, I., Fountoukis, C., Korhonen, H., Asmi, E., Laakso, L., Lihavainen, H., Swietlicki, E., Svenningsson, B., Asmi, A., Pandis, S. N., Kulmala, M., and Petäjä, T.: Cloud condensation nuclei production associated with atmospheric nucleation: a synthesis based on existing literature and new results, Atmos. Chem. Phys., 12, 1203712059, doi:10.5194/acp-12-12037-2012, 2012.

Kuang, C., McMurry, P. H., and McCormick, A. V.: Determination of cloud condensation nuclei production from measured new particle formation events, Geophys. Res. Lett., 36, L09822, doi:10.1029/2009GL037584, 2009.

Kulmala, M., Dal Maso, M., Makela, J. M., Pirjola, L., Vakeva, M., Aalto, P., Miikkulainen, P., Hameri, K., O’Dowd, C. D.: On the formation, growth and composition of nucleation mode particles. Tellus B, 53, 479-490, 2001.
Kulmala, M., Kontkanen, J., Junninen, H., Lehtipalo, K., Manninen, H. E., Nieminen, T., Petaja, T., Sipila, M., Schobesberger, S., Rantala, P., Franchin, A., Jokinen, T., Jarvinen, E., Aijala, M., Kangasluoma, J., Hakala, J., Aalto, P. P., Paasonen, P., Mikkila, J., Vanhanen, J., Aalto, J., Hakola, H., Makkonen, U., Ruuskanen, T., Mauldin, R. L., Duplissy, J., Vehkamaki, H., Back, J., Kortelainen, A., Riipinen, I., Kurten, T., Johnston, M. V., Smith, J. N., Ehn, M., Mentel, T. F., Lehtinen, K. E. J., Laaksonen, A., Kerminen, V. M., Worsnop, D. R..: Direct observations of atmospheric aerosol nucleation, Science, 339, 943-946, doi:10.1126/science.1227385, 2013.

Kulmala, M., Petaja, T., Nieminen, T., Sipila, M., Manninen, H. E., Lehtipalo, K., Dal Maso, M., Aalto, P. P., Junninen, H., Paasonen, P., Riipinen, I., Lehtinen, K. E. J., Laaksonen, A., Kerminen, V. M.: Measurement of the nucleation of atmospheric aerosol particles, Nature Protoc., 7, 1651-1667, 2012.

Kumar, P., Morawska, L., Birmili, W., Paasonen, P., Hu, M., Kulmala, M., Harrison, R. M., Norford, L., and Britter, R.: Ultrafine particles in cities, Environ. Int., 66, 1-10, 2014.

Kumar, P., Morawska, L., and Harrison, R. M.: Nanoparticles in European cities and associated health impacts, in: Urban Air Quality in Europe: The Handbook of Environmental Chemistry, edited by: Viana, M., Vol. 26, Springer, Berlin, Heidelberg, 339 365, doi:10.1007/698_2012_161,2013a.

Kumar, P., Pirjola, L., Ketzel, M., and Harrison, R. M.: Nanoparticle emissions from 11 non-vehicle exhaust sources - A review, Atmos. Environ., 67, 252-277, 2013b.

Kumar, P., Robins, A., Vardoulakis, S., and Britter, R.: A review of the characteristics of nanoparticles in the urban atmosphere and the prospects for developing regulatory controls, Atmos. Environ., 44, 5035-5052, 2010.

Kumar, P., Gurjar, B. R., Nagpure, A., and Harrison, R. H.: Preliminary estimates of particle number emissions from road vehicles in megacity Delhi and associated health impacts. Environ. Sci. Technol., 45, 5514-5521, 2011.

Laakso, L., Merikanto, J., Vakkari, V., Laakso, H., Kulmala, M., Molefe, M., Kgabi, N., Mabaso, D., Carslaw, K. S., Spracklen, D. V., Lee, L. A., Reddington, C. L., and Kerminen, V. M.: Boundary layer nucleation as a source of new $\mathrm{CCN}$ in savannah environment, Atmos. Chem. Phys., 13, 1957-1972, doi:10.5194/acp13-1957-2013, 2013.

Li, J., Zhuang, G. S., Huang, K., Lin, Y. F., Xu, C., and Yu, S. L.: Characteristics and sources of air-borne particulate in Urumqi, China, the upstream area of Asia dust, Atmos. Environ., 42, 776787, 2008.

Lihavainen, H., Kerminen, V. M., Komppula, M., Hatakka, J., Aaltonen, V., Kulmala, M., and Viisanen, Y.: Production of "potential" cloud condensation nuclei associated with atmospheric newparticle formation in northern Finland, J. Geophys. Res., 108, 4782, doi:10.1029/2003jd003887, 2003.

Lin, M., Holloway, T., Oki, T., Streets, D. G., and Richter, A.: Multiscale model analysis of boundary layer ozone over East Asia, Atmos. Chem. Phys., 9, 3277-3301, doi:10.5194/acp-9-3277-2009, 2009.

Lin, P., Hu, M., Wu, Z., Niu, Y., and Zhu, T.: Marine aerosol size distributions in the springtime over China adjacent seas, Atmos. Environ., 41, 6784-6796, 2007.

Liu, S., Hu, M., Wu, Z. J., Wehner, B., Wiedensohler, A., and Cheng, Y. F.: Aerosol number size distribution and new parti- 
cle formation at a rural/coastal site in Pearl River Delta (PRD) of China, Atmos. Environ., 42, 6275-6283, 2008.

Medalia, A. I., and Rivin, D.: Particulate carbon and other components of soot and carbon-black, Carbon, 20, 481-492, doi:10.1016/0008-6223(82)90084-7, 1982.

Merikanto, J., Spracklen, D. V., Mann, G. W., Pickering, S. J., and Carslaw, K. S.: Impact of nucleation on global CCN, Atmos. Chem. Phys., 9, 8601-8616, 2009,

http://www.atmos-chem-phys.net/9/8601/2009/.

Moffet, R. C., and Prather, K. A.: In-situ measurements of the mixing state and optical properties of soot with implications for radiative forcing estimates, P. Natl. Acad. Sci. USA, 106, 1187211877, 2009.

Mönkkönen, P., Koponen, I. K., Lehtinen, K. E. J., Hämeri, K., Uma, R., and Kulmala, M.: Measurements in a highly polluted Asian mega city: observations of aerosol number size distribution, modal parameters and nucleation events, Atmos. Chem. Phys., 5, 57-66, doi:10.5194/acp-5-57-2005, 2005.

Nel, A., Xia, T., Madler, L., and Li, N.: Toxic potential of materials at the nanolevel, Science, 311, 622-627, 2006.

Petters, M. D. and Kreidenweis, S. M.: A single parameter representation of hygroscopic growth and cloud condensation nucleus activity, Atmos. Chem. Phys., 7, 1961-1971, doi:10.5194/acp-71961-2007, 2007.

Reid, J. S., Koppmann, R., Eck, T. F., and Eleuterio, D. P.: A review of biomass burning emissions part II: intensive physical properties of biomass burning particles, Atmos. Chem. Phys., 5, 799825, doi:10.5194/acp-5-799-2005, 2005.

Salma, I., Borsós, T., Weidinger, T., Aalto, P., Hussein, T., Dal Maso, M., and Kulmala, M.: Production, growth and properties of ultrafine atmospheric aerosol particles in an urban environment, Atmos. Chem. Phys., 11, 1339-1353, doi:10.5194/acp11-1339-2011, 2011.

See, S. W., Balasubramanian, R., and Wang, W.: A study of the physical, chemical, and optical properties of ambient aerosol particles in Southeast Asia during hazy and nonhazy days, J. Geophys. Res., 111, D10S08, doi:10.1029/2005jd006180, 2006.

Seinfeld, J. H., and Pandis, S. N.: Atmos. Chem. Phys.. From air pollution to climate change, John Wiley \& Sons New York, 429443, 1998.

Shen, X. J., Sun, J. Y., Zhang, Y. M., Wehner, B., Nowak, A., Tuch, T., Zhang, X. C., Wang, T. T., Zhou, H. G., Zhang, X. L., Dong, F., Birmili, W., and Wiedensohler, A.: First long-term study of particle number size distributions and new particle formation events of regional aerosol in the North China Plain, Atmos. Chem. Phys., 11, 1565-1580, doi:10.5194/acp-11-15652011, 2011.

Reid, J. S., Eck, T. F., Christopher, S. A., Koppmann, R., Dubovik, O., Eleuterio, D. P., Holben, B. N., Reid, E. A., and Zhang, J.: A review of biomass burning emissions part III: intensive optical properties of biomass burning particles, Atmos. Chem. Phys., 5, 827-849, doi:10.5194/acp-5-827-2005, 2005.

Rose, D., Nowak, A., Achtert, P., Wiedensohler, A., Hu, M., Shao, M., Zhang, Y., Andreae, M. O., and Pöschl, U.: Cloud condensation nuclei in polluted air and biomass burning smoke near the mega-city Guangzhou, China - Part 1: Size-resolved measurements and implications for the modeling of aerosol particle hygroscopicity and CCN activity, Atmos. Chem. Phys., 10, 3365-3383, doi:10.5194/acp-10-3365-2010, 2010.
Wang, Z. B., Hu, M., Sun, J. Y., Wu, Z. J., Yue, D. L., Shen, X. J., Zhang, Y. M., Pei, X. Y., Cheng, Y. F., and Wiedensohler, A.: Characteristics of regional new particle formation in urban and regional background environments in the North China Plain, Atmos. Chem. Phys., 13, 12495-12506, doi:10.5194/acp-1312495-2013, 2013a.

Wang, Z. B., Hu, M., Yue, D. L., He, L. Y., Huang, X. F., Yang, Q., Zheng, J., Zhang, R. Y., and Zhang, Y. H.: New particle formation in the presence of a strong biomass burning episode at a downwind rural site in PRD, China, Tellus B, 65, 19965, doi:10.3402/tellusb.v65i0.19965, 2013b.

Wang, Z. B., Hu, M., Yue, D. L., He, L. Y., Huang, X. F., Yang, Q., Zheng, J., Zhang, R. Y., and Zhang, Y. H.: New particle formation in the presence of a strong biomass burning episode at a downwind rural site in PRD, China, Tellus B, 65, 19965, doi:10.3402/tellusb.v65i0.19965, 2013c.

Wehner, B. and Wiedensohler, A.: Long term measurements of submicrometer urban aerosols: statistical analysis for correlations with meteorological conditions and trace gases, Atmos. Chem. Phys., 3, 867-879, doi:10.5194/acp-3-867-2003, 2003.

Wehner, B., Wiedensohler, A., Tuch, T. M., Wu, Z. J., Hu, M., Slanina, J., and Kiang, C. S.: Variability of the aerosol number size distribution in Beijing, China: new particle formation, dust storms, and high continental background, Geophys. Res. Lett., 31, L22108, doi:10.1029/2004GL021596, 2004.

WHO: Review of evidence on health aspects of air pollution REVIHAAP. World Health Organisation, Regional Office for Europe, available at: http://www.euro.who.int/_data/assets/pdf_ file/0020/182432/e96762-final.pdf (last access: 5 June 2014), 2013.

Wiedensohler, A., Cheng, Y. F., Nowak, A., Wehner, B., Achtert, P., Berghof, M., Birmili, W., Wu, Z. J., Hu, M., Zhu, T., Takegawa, N., Kita, K., Kondo, Y., Lou, S. R., Hofzumahaus, A., Holland, F., Wahner, A., Gunthe, S. S., Rose, D., Su, H., and Poschl, U.: Rapid aerosol particle growth and increase of cloud condensation nucleus activity by secondary aerosol formation and condensation: a case study for regional air pollution in northeastern China, J. Geophys. Res.-Atmos., 114, D00G08, doi:10.1029/2008JD010884, 2009.

Willeke, K. and Baron, P. A.: Aerosol Measurement Principles, Techniques, and Applications, Van Nostrand Reinhold, Hoboken, NJ, 1993.

Wu, Z.J., Hu, M., Lin, P., Liu, S., Wehner, B., and Wiedensohler, A.: Particle number size distribution in the urban atmosphere of Beijing, China, Atmos. Environ., 42, 7967-7980, 2008.

Wu, Z. J., Hu, M., Liu, S., Wehner, B., Bauer, S., Ssling, A. M., Wiedensohler, A., Petaja, T., Dal Maso, M., and Kulmala, M.: New particle formation in Beijing, China: Statistical analysis of a 1-year data set, J Geophys. Res., 112, D09209, doi:10.1029/2006JD007406, 2007.

$\mathrm{Xu}, \mathrm{P}$. , Chen, Y. F., and Ye, X. J.: Haze, air pollution, and health in China, Lancet, 382, 2067-2067, 2013.

Yli-Juuti, T., Riipinen, I., Aalto, P. P., Nieminen, T., Maenhaut, W., Janssens, I. A., Claeys, M., Salma, I., Ocskay, R., Hoffer, A., Imre, K., and Kulmala, M.: Characteristics of new particle formation events and cluster ions at K-puszta, Hungary, Boreal Environ. Res., 14, 683-698, 2009.

Yu, F., Luo, G., Liu, X., Easter, R. C., Ma, X., and Ghan, S. J.: Indirect radiative forcing by ion-mediated nucleation of aerosol, 
Atmos. Chem. Phys., 12, 11451-11463, doi:10.5194/acp-1211451-2012, 2012.

Yu, H., Hallar, A. G., You, Y., Sedlacek, A., Springston, S., Kanawade, V. P., Lee, Y. N., Wang, J., Kuang, C. G., McGraw, R. L., McCubbin, I., Mikkila, J., Lee, S. H.: Sub-3nm particles observed at the coastal and continental sites in the United States, J. Geophys. Res., 119, 860-879, 2014.

Yue, D. L., Hu, M., Zhang, R. Y., Wang, Z. B., Zheng, J., Wu, Z. J., Wiedensohler, A., He, L. Y., Huang, X. F., and Zhu, T.: The roles of sulfuric acid in new particle formation and growth in the mega-city of Beijing, Atmos. Chem. Phys., 10, 4953-4960, doi:10.5194/acp-10-4953-2010, 2010.

Yue, D. L., Hu, M., Zhang, R. Y., Wu, Z. J., Su, H., Wang, Z. B., Peng, J. F., He, L. Y., Huang, X. F., Gong, Y. G., and Wiedensohler, A.: Potential contribution of new particle formation to cloud condensation nuclei in Beijing, Atmos. Environ., 45, 6070-6077, 2011.
Yue, D. L., Hu, M., Wang, Z. B., Wen, M. T., Guo, S., Zhong, L. J., Wiedensohler, A., and Zhang, Y. H.: Comparison of particle number size distributions and new particle formation between the urban and rural sites in the PRD region, China, Atmos. Environ., 76, 181-188, 2013.

Zhang, R. Y.: Getting to the Critical Nucleus of Aerosol Formation, Science, 328, 1366-1367, 2010.

Zhang, R. Y., Khalizov, A., Wang, L., Hu, M., and Xu, W.: Nucleation and Growth of Nanoparticles in the Atmosphere, Chem. Rev., 112, 1957-2011, 2012.

Zhang, Y. H., Hu, M., Zhong, L. J., Wiedensohler, A., Liu, S. C., Andreae, M. O., Wang, W., and Fan, S. J.: Regional Integrated Experiments on Air Quality over Pearl River Delta 2004 (PRIDE-PRD2004): Overview, Atmos. Environ., 42, 6157-6173, 2008. 